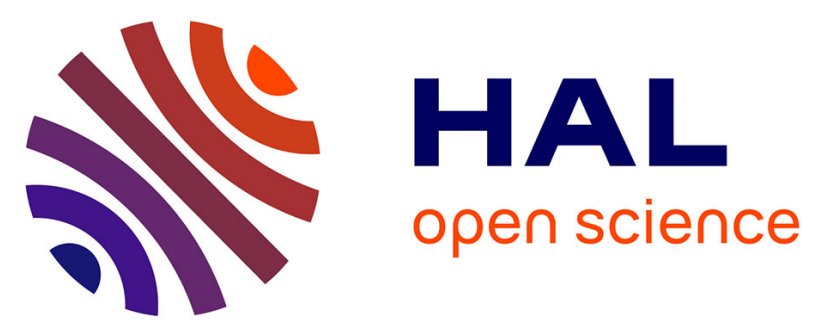

\title{
A mass stranding of seven Longman's beaked whales (Indopacetus pacificus) in New Caledonia, South Pacific
}

Claire Garrigue, Marc Oremus, Rémi Dodémont, Paco Bustamante, Olivier Kwiatek, Geneviève L Libeau, Christina L Lockyer, Jean-Christophe Vivier, Merel L Dalebout

\section{To cite this version:}

Claire Garrigue, Marc Oremus, Rémi Dodémont, Paco Bustamante, Olivier Kwiatek, et al.. A mass stranding of seven Longman's beaked whales (Indopacetus pacificus) in New Caledonia, South Pacific. Marine Mammal Science, 2016, 32 (3), pp.884 - 910. 10.1111/mms.12304 · hal-01389067

\section{HAL Id: hal-01389067 https://hal.science/hal-01389067}

Submitted on 27 Oct 2016

HAL is a multi-disciplinary open access archive for the deposit and dissemination of scientific research documents, whether they are published or not. The documents may come from teaching and research institutions in France or abroad, or from public or private research centers.
L'archive ouverte pluridisciplinaire $\mathbf{H A L}$, est destinée au dépôt et à la diffusion de documents scientifiques de niveau recherche, publiés ou non, émanant des établissements d'enseignement et de recherche français ou étrangers, des laboratoires publics ou privés. 
A mass stranding of seven Longman's beaked whales (Indopacetus pacificus) in New Caledonia, South Pacific

Claire Garrigue $^{1 *}$, Marc Oremus ${ }^{1}$, Rémi Dodémont ${ }^{1}$, Paco Bustamante ${ }^{2}$, Olivier Kwiatek ${ }^{3}$, Geneviève Libeau ${ }^{3}$, Christina Lockyer ${ }^{4}$, Jean-Christophe Vivier ${ }^{5}$, Merel L. Dalebout ${ }^{6}$

1 Opération Cétacés BP 12827, 98802 Noumea, New Caledonia; Contact details: claire.garrigue@ird.fr

${ }^{2}$ Littoral Environnement et Sociétés (LIENSs), UMR 7266 CNRS - Université de La Rochelle, 2 Rue Olympe de Gouges ,17000 La Rochelle, France

${ }^{3}$ Centre de coopération internationale en recherche agronomique pour le développement CIRAD, UMR CMAEE, F-34398 Montpellier, France; INRA, UMR 1309 CMAEE, F-34398 Montpellier, France

${ }^{4}$ Age Dynamics, Huldbergs Allé 42, 2800 Kongens Lyngby, Denmark

${ }^{5}$ Clinique Vétérinaire de Ste-Marie 6 rue Schmidt, Nouméa

${ }^{6}$ School of Biological, Earth, and Environmental Sciences, University of New South Wales, Kensington, NSW 2052, Australia

*Curent affiliation: Institut de Recherche pour le Développement, UMR ENTROPIE, UPVD, 52 avenue Paul Alduy 66860 Perpignan, France 
Abstract: Seven Longman's beaked whales (Indopacetus pacificus) stranded together in southern New Caledonia on 16 November 2013 (one adult male, two adult females, two subadult females, one calf, and one unknown). At this time, we have no evidence to suggest that this event was an "atypical" mass stranding associated with active naval sonar or other anthropogenic activities. The adult females were slightly larger $(618-640 \mathrm{~cm})$ than the adult male $(590 \mathrm{~cm})$. The length of the calf $(\mathrm{ca} .300 \mathrm{~cm})$ suggests it was less than a year old. Five of the whales were sampled for mitochondrial (mt) DNA analysis to confirm species identification. All shared the same haplotype over $680 \mathrm{bp}$ of the mtDNA control region. High concentrations of $\mathrm{Hg}, \mathrm{Fe}, \mathrm{Se}, \mathrm{Zn}$ (all in the liver), and $\mathrm{Cd}$ (in the kidneys) were detected. Necropsies revealed plastic debris in the stomach of two of the whales. One of these same whales had chronic gastritis while the other had acute pleurisy and also tested positive for morbillivirus. This infection may have been a major factor behind this mass stranding event.

Keywords: mass stranding, DNA species identification, morbillivirus, marine debris, heavy metal pollution, external appearance, age, tropical bottlenose whale, Ziphiidae

Short title: Longman's beaked whales stranded in New Caledonia. 


\section{Introduction}

Longman's beaked whale (Indopacetus pacificus) has long been considered one of the rarest and least known of all whales. First described from a beachcast skull found in northern Queensland, Australia, as the largest member of the genus Mesoplodon (Longman 1926), it was later elevated to its own genus, Indopacetus, after comprehensive morphological evaluation (Moore 1968) and the discovery of a second skull in Somalia (Azzaroli 1968). Astute observers of unidentified "tropical bottlenose whales" at sea in the Indian and Pacific Oceans had also suggested that these animals might in fact represent Longman's beaked whales (Mörzer Bruyns 1971, Pitman et al. 1999). This hypothesis was confirmed by Dalebout et al. (2003) who described the external appearance of Indopacetus for the first time by linking the holotype skull to several complete stranded specimens from South Africa through DNA analysis. Groups of Indopacetus are encountered with some regularity in the tropical Indian and Pacific Oceans (Anderson et al. 2006, Afsal et al. 2009, Yamada et al. 2012), and there are occasional reports of strandings from the same area. In a recent review, Yamada et al. (2012) summarized the current state of knowledge of this species ( $<20$ stranded animals to date). All strandings have been singletons, with the exception of a cow-calf pair in Taiwan (Yao et al. 2012). The most recent recorded stranding was a juvenile male from Hawaii (West et al. 2013).

None of the 22 species in the family Ziphiidae (beaked whales) appear to be particularly common. Their open-ocean, pelagic distribution, deep-diving ability, and generally short surface times, together with the difficulty in confirming species identification at sea has resulted in far less being known about this group than about most other toothed whales (Jefferson et al. 2008). For the majority of species, most information has been collected from dead stranded animals. Long-term studies have been conducted on only three species; the northern bottlenose whale (Hyperoodon ampulatus), Cuvier's beaked whale (Ziphius cavirostris) and Blainville's beaked whale (Mesoplodon densirostris) (e.g., Whitehead et al. 1997, Gowans et al. 2001, Hooker et al. 2002, Baird et al. 2006, McSweeney et al. 2007). With the exception of Gray's beaked whale (Mesoplodon grayi), beaked whales do not appear to mass strand naturally; they usually strand singly or as cow-calf pairs (von Haast 1876, Dalebout 2002). In recent decades, however, a series of "atypical" mass strandings of various species of beaked whales has highlighted their vulnerability to anthropogenic sounds, such as active naval sonar and seismic testing (e.g., D’Amico et al. 2009).

Here we report on a mass stranding of Longman's beaked whales in New Caledonia in the southwest Pacific Ocean. At this time, we have no evidence to suggest that this event was 
an "atypical" mass stranding associated with active naval sonar or other anthropogenic activities. Of the seven animals that came ashore together on the south coast of the Grande Terre on 16 November 2013, four ultimately died (one adult male, one adult female, two subadult females). The other three whales (one cow-calf pair and one unidentified animal) were successfully refloated and not seen again. This study presents biological data from these animals, including one of the first confirmed adult males recorded for this species, including assessment of genetic identity, trophic ecology and health, and age. We also discuss the implications for social structure in these poorly known whales.

The presence of this species in New Caledonia had previously been confirmed from two at-sea sightings, in the oceanic waters west of the Grande Terre, and in the Loyalty Islands (Garrigue and Poupon 2013). Additional at-sea sightings have since been made during recent aerial surveys undertaken as part of the REMMOA project, conducted by UMS Pelagis (Université de La Rochelle) and the French Agency for Marine Protected Areas, to investigate the distribution and abundance of megafauna in New Caledonia's EEZ. To the best of our knowledge, Longman's beaked whale has yet to be reported from other islands of the south Pacific (Miller 2007).

\section{Methods}

Study site

New Caledonia is an island archipelago situated in the Tropic of Capricorn, approximately 1,200 km east of Australia. It consists of the main island (Grande Terre, a fragment of the old Gondwana supercontinent), together with the Loyalty Islands (Ouvéa, Lifou, Tiga, and Maré) to the east, Isle des Pins in the south, and the Belep Islands in the north. The Chesterfield Reef complex further to the west is also part of New Caledonia. The Grande Terre is surrounded by a barrier reef over $1,600 \mathrm{~km}$ long that encompasses a massive lagoon, almost 25,000 $\mathrm{km}^{2}$ in area (average depth, $24 \mathrm{~m}$ ). Baie du Prony is a large bay (maximum depth, $40 \mathrm{~m}$ ) in the southern region of the Grande Terre, and has a wide mouth, allowing easy access to the lagoon and open ocean beyond. Baie de la Somme, the location of the stranding, is part of the north western zone of Baie du Prony (Fig. 1). 


\section{Description of Event and Data Collection}

On 15 November 2013, a group of seven to eight beaked whales were reported swimming near the mouth of Baie du Prony. On 16 November, between 1130 and 1200, recreational divers reported seven whales (one adult male, five females (two adults, two subadults, and one calf), and one unknown) beaching themselves on the mud-sand beach of Baie de la Somme $\left(22^{\circ} 19.8^{\prime} \mathrm{S}, 166^{\circ} 49.3^{\prime} \mathrm{E}\right)$. Locals attempted to rescue the whales by pushing them back into deeper water. Based on observations, photos, and video footage taken at this time, all of the whales appeared to be in relatively good condition with no obvious external injuries, except for cookie-cutter shark bites (Isistius spp.). All of the whales that were refloated returned to the beach at least once, and one returned at least 5-6 times (\#1, adult female). This animal was the largest in the group (total length TL, $640 \mathrm{~cm}$ ), and was accompanied by a younger animal that was likely her calf (\#3). Both these whales were ultimately refloated successfully. One of the whales was unable to stay upright by itself (\#2, adult male). Rescuers attempted to hold it upright to allow it to reestablish its balance and equilibrium but to no avail. When it was next observed, it was on its side again and eventually died. By 1430, the other six whales had been refloated and appeared to be swimming out of the Baie de la Somme. At 1700, four of the whales were observed swimming in the nearby Baie du Carénage (Fig. 1), (including the mother and calf (as recognized from video footage). The "service des gardes nature" (environmental department rangers) disposed of the carcass of the dead whale (\#2) by towing it out to deeper waters beyond the reef.

On 17 November 2013, three of the whales (\#4, 5, 6: two subadult females, one adult female) were found dead on the same beach at Baie de la Somme where they had stranded the previous day, at a distance of 10-20 m from one another. These animals were examined with the help of a professional veterinarian (JCV) and further data collected (Table 1). A brief necropsy was performed for each animal, focusing on the peritoneal cavity (including stomach contents), heart, and lungs. As much information as possible was gathered from the stranded whales, but due to the rising tide, remote location and logistics involved, only a fraction of the data that we would have liked to collect was able to be obtained. The head of whale \#4 was buried in the upper part of the beach, together with a small amount of postcranial material. The carcasses, including the head of whale \#5, were subsequently removed to the local rubbish dump. The same day, at 1700, a calf (\#3, as identified from photos) was reported stranded again at nearby Baie Nord. It was not accompanied by the adult (\#1) assumed to be its mother. It was successfully refloated by locals and was not seen again. 
On 18 November around 1200 we encountered two Longman's beaked whales swimming in nearby Baie du Carénage. They were traveling fast (ca. 6 knots) during the time we observed them and were heading for open water. Further sightings of what may have been the same two Longman's beaked whales were made by locals on 23 and 24 November in Baie du Prony. Reports indicated that the whales were being followed by sharks. The last observation was on 30 November. Only one whale was seen at that time and photos were obtained.

\section{Analyses Conducted}

Genetics - Total cellular DNA was isolated from skin samples using a Qiagen DNeasy kit. An 800 base pair (bp) fragment of the 5' end of the mitochondrial (mt) DNA control region (d-loop) was amplified using the polymerase chain reaction (PCR) and the primers, light-strand tPro-whale M13-Dlp1.5 and heavy strand Dlp8G (as reported in Dalebout et al. 2005). All PCR reactions were carried out under the conditions reported in Oremus et al. (2007). PCR products were purified for sequencing with Sephadex ${ }^{\circledR}$ G50 and sequenced in both directions with BigDyeTM terminator chemistry on an ABI3100 DNA sequencer (Applied Biosystems). Sequences were aligned using the MUSCLE alignment method with the default setting (Edgar 2004), as implemented in the software GENEIOUS v.6 (Drummond et al. 2009). Variable sites were confirmed by visual inspection of peak heights.

To confirm species identity as determined from field observations, we submitted our mtDNA sequences to the web-based DNA identification program for cetaceans, DNAsurveillance (Ross et al. 2003). To investigate population level genetic diversity in this species, we assembled mtDNA control region haplotypes from previously published and unpublished studies as available from GenBank, with sequence lengths ranging from 226 to $460 \mathrm{bp}$ (Table 2). Standard indices of genetic variation (nucleotide diversity, $\pi$, and haplotype diversity, $h$ (Nei 1987)) were estimated over all samples available, using the software ARLEQUIN (Excoffier and Lischer 2010). The sex of sampled specimens was determined/confirmed by multiplex PCR amplification of the male-specific SRY gene together with a fragment from the ZFY/ZFX gene as a positive control (Gilson et al. 1998).

Age Estimation - Age was estimated using a single tooth from each of four animals examined. Each tooth was thoroughly cleaned of gum tissue and $2-3$ sections, ca. $150 \mu \mathrm{m}$ thick, were cut centrally through the crown and root of each tooth. These thin sections were examined under a microscope at magnification $\mathrm{x} 7-\mathrm{x} 40$ using transmitted polarized light, 
focusing on both dentinal and cementum Growth Layer Groups (GLGs). Each GLG observed was assumed to have been deposited over a 1-year period. In addition, a thicker central wafer $(2-2.5 \mathrm{~mm}$ ) was removed from each tooth and decalcified in RDO solution (a proprietory brand, Illinois, USA). Thin sections of $(12-20 \mu \mathrm{m})$ of this central wafer were then made using a freezing microtome and stained with Ehrlich's Acid Hæmatoxylin as described for other species (Lockyer 1993, Lockyer and Braulik 2014). Plain transmitted light was then used for examination under a microscope as for the unstained sections.

Trace Elements - Trace element analysis was performed by the commercial company, AEL, Noumea, New Caledonia. Frozen tissue and organ samples (muscle, liver, and kidney) were lyophilized for $48 \mathrm{~h}$ and ground into fine powder. Total Mercury $(\mathrm{Hg})$ concentrations were determined by direct analysis of the tissue powder with an Advanced Mercury Analyzer (ALTEC AMA 254) using $1-5 \mathrm{mg}$ of dry sample weighed to the nearest $0.01 \mathrm{mg}$ (Bustamante et al. 2006). Samples were heated progressively to $800{ }^{\circ} \mathrm{C}$ to evaporate the metal, then held in an $\mathrm{O}_{2}$ atmosphere for $3 \mathrm{~min}$, with subsequent amalgamation on a gold net. The net was then heated to liberate the collected $\mathrm{Hg}$, which was measured by atomic absorption spectrophotometry.

For the other 13 metal elements analyzed, the preparation protocol was as follows. Aliquots of the samples $(0.5 \mathrm{~g})$ were digested in $4 \mathrm{~mL}$ of $\mathrm{HNO}_{3}$ and $1 \mathrm{~mL}$ of $\mathrm{H}_{2} \mathrm{O}_{2}$ in a ETHOS microwave for $20 \mathrm{~min}$ at $196^{\circ} \mathrm{C}(1500 \mathrm{~W})$. The digested solutions were diluted in $20 \mathrm{~mL}$ of milli-Q water. Silver $(\mathrm{Ag})$, arsenic (As), cadmium $(\mathrm{Cd})$, cobalt $(\mathrm{Co})$, chromium $(\mathrm{Cr})$, copper $(\mathrm{Cu})$, iron $(\mathrm{Fe})$, manganese $(\mathrm{Mn})$, nickel $(\mathrm{Ni})$, lead $(\mathrm{Pb})$, selenium $(\mathrm{Se})$, vanadium $(\mathrm{V})$, and zinc (Zn) were analyzed using Induced Coupled Plasma Optical Emission Spectrometry (ICP-OES) with a Varian 730-ES. For each set of samples, accuracy and reproducibility were tested by running analytical blanks and multiple replicates of lobster hepatopancreas (TORT-2) and dogfish muscle (DORM-3) reference standards (National Research Council, Canada). Element concentrations are expressed as $\mu \mathrm{g} \cdot \mathrm{g}^{-1}$ of dry weight (dw).

Stable Isotopes - Stable isotope analyses were conducted to obtain information on the feeding habitats of whales $\left(\delta^{13} \mathrm{C}\right)$ and their trophic position in the food web $\left(\delta^{15} \mathrm{~N}\right)$. As the turnover time of these elements varies by tissue type, from several days (e.g., liver) to several months (e.g., muscle), four different tissues were analyzed (muscle, liver, kidney, and skin). As lipids are highly depleted in ${ }^{13} \mathrm{C}$ relative to other tissue components (De Niro and Epstein, 
1977), lipids were first removed from all samples using cyclohexane, as described by Chouvelon et al. (2011). Subsamples of lipid-free tissue powder $(0.30 \pm 0.05 \mathrm{mg})$ were then weighed in tin cups for stable isotope analysis. Isotopic analyses were performed at the laboratory of Littoral Environnement et Sociétés (LIENSs), France, using a Thermo Scientific Delta V Advantage mass spectrometer coupled to a Thermo Scientific Flash EA1112 elemental analyzer. The results are presented in the usual $\delta$ notation relative to the deviation from standards (Pee Dee Belemnite for $\delta^{13} \mathrm{C}$ and atmospheric nitrogen for $\delta^{15} \mathrm{~N}$ ), in parts per thousand (\%). Based on replicate measurements of internal laboratory standards, the experimental precision is \pm 0.15 and $\pm 0.20 \%$ for $\delta^{13} \mathrm{C}$ and $\delta^{15} \mathrm{~N}$, respectively.

Morbillivirus: Detection - To investigate the possible presence of cetacean morbillivirus (CeMV), RNA amplification was conducted via one-step RT-PCR with a set of universal-morbillivirus primers based on the conserved sequence of the phosphoprotein $\mathrm{P}$ gene, as described by Barrett et al. (1993). RNA amplification is expected to yield a positive result only if morbillivirus is present. These analyses were conducted on spleen and liver of three whales (\#A, B, C) as well as on lung tissue for whale \#C. In brief, viral RNA was extracted from $150 \mu \mathrm{l}$ of each sample using an RNA virus isolation kit (Macherey Nagel). Universalmorbillivirus primers, UP-P1 and UP-P2, allow the amplification of a phosphoprotein P gene fragment, $429 \mathrm{bp}$ in length, between positions 400 and 828. RNA was isolated from Vero cells infected with Peste-des-petits ruminants virus (PPRV), or from dolphin morbillivirus (DMV) as a positive control. The $45 \mu \mathrm{L}$ PCR reaction mix consisted of $15 \mu \mathrm{LddH} \mathrm{d}_{2} \mathrm{O}, 10 \mu \mathrm{L} 5 \mathrm{X}$ buffer, $2 \mu \mathrm{L}$ dNTP mix, $10 \mu \mathrm{L} \mathrm{Q}$ solution, and $3 \mu \mathrm{L}$ of each primer at a $10 \mu \mathrm{M}$ concentration. An aliquot of previously extracted RNA $(5 \mu \mathrm{L})$ was used as a sample.

Morbillivirus: Analysis of Sequence Data - Where PCR amplification of morbillivirus RNA was successful, the resulting fragment was sequenced. Sequencing reactions were performed by the company, CoGenics. The sequences obtained were trimmed to remove primer-related data and aligned with Morbillivirus sequences (e.g., BWMV, beaked whale morbillivirus; CMV, cetacean morbillivirus; DMV, dolphin morbillivirus; PMV, porpoise morbillivirus; PPRV, peste-des-petits-ruminants; PWMV, pilot whale morbillivirus) obtained from GenBank, using the program, Clustal W program as implemented in MEGA (Tamura et al. 2013). The alignment included two unpublished $P$ sequences from Indo-Pacific bottlenose dolphins (Tursiops aduncus) in Western Australia (courtesy of N. Stephens, Murdoch 
University, Western Australia). Phylogenetic analysis based on 280 nucleotides of the P gene was carried out by means of the "criterion of neighborhood based on the principle of parsimony" (Saitou and Nei 1987). Trees were generated using the unweighted NeighborJoining method of Gascuel (1997) using MEGA 6, and the robustness of internal nodes assessed via 1,000 bootstrap replicates. Trees were visualized via the program, Figtree v1.4 (A. Rambaut; available at http://tree.bio.ed.ac.uk/software/figtree/).

\section{Results}

\section{Osteological Material Held}

The material collected from the two subadult females (\#4 and 5) that was buried on the beach at Baie de la Somme and in the local rubbish dump was recovered in June and July 2014, respectively. Two skulls and a small number of vertebrae were donated to the Museum of Queensland in Brisbane, Australia (specimen accession numbers: QMJM20269 and QMJM20270). This museum also holds the holotype for this species. The teeth from whales \#2, 4, 5 and 6 are held in the collection of Opération Cétacés.

\section{External appearance}

External measurements were obtained from six animals (Table 3). The adult male (\#2) was $590 \mathrm{~cm}$ long. Although somewhat shorter than the two adult females (\#1 and 6), the male was considered physically and sexually mature based on its adult coloration and erupted teeth (see below). The sexual maturity of the females was determined from color pattern (see below). The length of the calf (\#3) was estimated at $300 \mathrm{~cm}$ from photographs and video footage and comparisons to the adult female (\#1) assumed to be its mother.

All the whales had rounded, robust bodies with large melons and long beaks. The bottom jaw extended beyond the upper jaw. The dorsal fin was relatively large and erect. The pectoral fins were small and dark. The tail fluke had no central notch. The majority of external measurements showed similar ratios over the animals measured with respect to percentage of total length (Table 3). There were three exceptions. The distance from tip of the beak to tip of the dorsal fin (measurement 7 ) appeared to be proportionately greater in the adult male (\#2, $68 \%$ ) than in the two subadult females (\#4, 62\%; \#5, 54\%). The latter female was the same length as the adult male (TL $590 \mathrm{~cm}$ ). The proportional width of the flukes (measurement 16) was slightly greater in the adult male $(\# 2,25 \%)$ compared to the adult female $(\# 6,23 \%)$ and 
subadult females (22\%-23\%). The girth at the axilla (measurement 19) also appeared to be proportionately greater in the adult male $(\# 2,51 \%)$ than in the adult female $(\# 6,43 \%)$ and subadult females $(45 \%-46 \%)$. It is recognized, however, that our sample size is very small and some measurements, such as girth, could been influenced by the health of the individuals concerned.

Age-related color differences were observed. The adult male and the two females over $600 \mathrm{~cm}$ in length (\#1 and \#6) were dark gray-blue dorsally and paler gray ventrally, shading to white around the genital region (Fig. 2). The face area was also pale (Fig. 3A, B). All three adults were very heavily marked with pale cookie-cutter shark bite scars giving them a speckled or spotted appearance (Fig. 2). The color pattern of the subadult females and calf was similar to that of the subadult males described by Dalebout et al. (2003). There was a darker gray-black patch surrounding the eye with a variable band of darker pigment continuing up behind the blowhole. The paler "ear patch" as noted by Pitman et al. (1999) was also apparent. These animals had high, pale sides with a wash of darker coloration extending from the dorsum towards the pectoral fin. The subadults were also marked with cookie-cutter shark scars, but not as heavily as the adults. The calf did not appear to have any scars of this type. For all animals, the tail flukes were gray both dorsally and ventrally, with black margins. The ventral surface featured a series of lighter streaks.

A single pair of conical teeth was visible at the apex of the lower jaw of the adult male (\#2, Fig. 4). There were several soft barnacles attached. The teeth were worn at the tips and several pale linear tooth rake scars were visible on the flanks, likely due to interactions with conspecific adult males (Fig. 5). The females possessed a similar pair of conical teeth at the apex of the jaw but these were unerupted and covered by gum tissue. The teeth of the adult male were ca. $4.2 \mathrm{~cm}$ in length and quite bulbous at the base ("pear shaped," Fig. 6A). The teeth of the females examined $(\# 4,5,6)$ were a similar size, ca. $3.5 \mathrm{~cm}$ in length, but more slender with sharply pointed tips (Fig. 6B). No other teeth were present in the jaw of the male or females, as expected for this species. The tooth sockets (alveoli) of the adult male were a similar depth to those of the females (Fig. 7).

\section{Clinical Examination and Necropsy Results}

Externally, the animals appeared to be in good condition and they did not appear exhausted from the extensive struggling as may be expected of live stranded whales. With the exception of cookie-cutter shark scars, there was no evidence of shark or killer whale attacks. 
Some of the whales had fresh small abrasions likely resulting from the contact with corals in shallow water. For the two adult females (\#1 and \#6), the tip of the lower jaw was deeply abraded, enough to reveal a glimpse of the teeth normally hidden by gum tissue. This damage probably resulted from attempts to dive in the shallow waters of the bay as suggested by video footage taken on 16 November. No blood was visible at the ear opening or around the eyes.

During the necropsies (animals \#4, 5, and 6), the chest cavities were opened and stomachs collected for further inspection. These stomachs were relatively simple and appeared to consist of only two pockets. No signs of putrefaction or tissue change due to morbidity were observed. No histopathology analyses were conducted, but based on the gross observation at the time of necropsy, there were no obvious sign of vascular embolism.

For animal \#4 (subadult female), no anatomical lesions were noted, the heart weighed 7 $\mathrm{kg}$, and the ratio of the left to right ventrical was 5:1. Trabeculae carnae (round muscular cords found in both ventricles) were greatly developed compared to the heart of terrestrial mammals. The stomach was empty. The lateral blubber thickness was $3.1 \mathrm{~cm}$.

Animal \#5 (subadult female) showed a chronic gastritis in the first pocket of the stomach with deep, longitudinal lesions running in parallel along the main line of the stomach. Some of these lesions appeared very active, while others were healed and closed by fibrin. A supermarket-style plastic bag was found in the main stomach compartment, but was not blocking any stomach openings. The lateral blubber thickness was $3.8 \mathrm{~cm}$.

The heart of animal \#6 (adult female) weighted $10.5 \mathrm{~kg}$ and no lesions were noted. Multiple signs of acute pleurisy (inflammation of the lung membranes) were observed. The blood vessels of the lungs were congested, with a number of round, hemorrhagic petechiae on the pleura. There were also some areas of superficial atelectasis (lung tissue collapse), but without inflammation indicating that these were old lesions. A small zone of emphysema was found on the distal part of the lung. There were also some thin, long worms crawling on the surface of the tissue. There was no pulmonary edema. A little square of hard, dark-colored plastic, ca. $394 \mathrm{~cm} 2$, was found in the stomach. This animal had the thinnest lateral blubber layer of the three examined $(2.3 \mathrm{~cm})$.

The first five cervical vertebrae collected (animals \#4 and 5) were fused (of C7 total).

\section{Genetics}

A $680 \mathrm{bp}$ fragment of the mtDNA control region was successfully sequenced from all five whales sampled. Molecular species identification via DNA Surveillance (Ross et al. 2003) 
was consistent with identification based on morphological characteristics, with the DNA sequences from these animals clustering together with the reference sequences for Longman's beaked whale with $100 \%$ bootstrap support. All five whales represented the same mtDNA haplotype (i.e., same maternal lineage) for the $680 \mathrm{bp}$ fragment that was analyzed. We have referred to this as the New Caledonia (NC) haplotype" (GenBank Accession No., KP892561). This haplotype appears to be the same as that reported by Dalebout et al. (2003) from a Maldives adult female, based on the short $226 \mathrm{bp}$ fragment available for this specimen. Comparisons to other published sequences revealed only low level intraspecific variation; 1-5 bp difference from the NC haplotype. Indices of genetic diversity were calculated using the short $226 \mathrm{bp}$ fragment covered by all Longman's beaked whale sequences currently available. Only one of the NC animals was used in these analyses. Haplotype diversity was $h=0.821 \pm 0.101$, and nucleotide diversity was $\pi=0.595 \pm 0.117 \%$.

\section{Age Estimation}

A single tooth from each of four animals was examined. Age estimates from both the unstained and stained preparation methods, based on dentine and cementum GLGs, were recorded (Table 4). Both methods of preparation were found to be adequate for identifying GLGs.

Over 20 GLGs were observed in the teeth of both adult animals (male \#2, female \#6; Fig. 8A). Based on analyses of GLG patterns in other cetaceans (Perrin and Myrick 1980), this suggests these whales were each at least $20 \mathrm{yr}$ old. Of the subadult females, whale \#4 was estimated to be 8-9 yr old, while whale \#5 was estimated to be 13-14 yr old. For three of the whales (\#2, 4, and 5), the roots of the teeth showed extensive resorption in the dentine (Fig. $8 B)$.

\section{Trace Elements}

Of the tissues analyzed (muscle, kidney and liver), the liver is the most important accumulating organ, especially for metals such as $\mathrm{As}, \mathrm{Cu}, \mathrm{Fe}, \mathrm{Hg}, \mathrm{Mn}, \mathrm{Se}$, and $\mathrm{Zn}$. Very elevated concentrations of $\mathrm{Fe}, \mathrm{Hg}, \mathrm{Se}$ and $\mathrm{Zn}$ were found in the liver (Table 5). High concentrations of Cd were found in the kidneys (195 $\pm 43 \mu \mathrm{g} / \mathrm{g} \mathrm{dw})$, as well as the liver $(1,369$ $\pm 36 \mu \mathrm{g} / \mathrm{g} \mathrm{dw}$ ). In contrast, concentrations of $\mathrm{Ag}, \mathrm{Co}, \mathrm{Cr}, \mathrm{Ni}, \mathrm{Pb}$, and $\mathrm{V}$ were all close or below the level of detection. For some elements, concentration in the tissues appeared to increase with age of the whales, from youngest \#4 to oldest \#6 (e.g., Cd, Hg, and Se), though there was some 
variation by tissue type. For example, whale \#5 had far lower concentrations of $\mathrm{Hg}$ in the kidneys compared to the other two whales, and Cd concentrations in the kidneys were highest in the youngest whale (\#4) and lowest in the oldest (\#6).

\section{Stable isotopes}

The $\delta^{13} \mathrm{C}$ mean and SD values were $-17.02 \pm 0.30$ in the skin, $-16.22 \pm 0.18$ in the muscle, $-16.89 \pm 0.14$ in the liver, and $-16.99 \pm 0.55$ in the kidney. For $\delta^{15} \mathrm{~N}$, average values were $13.33 \pm 0.33$ in the skin, $12.83 \pm 0.40$ in the muscle, $13.14 \pm 0.59$ in the liver, and 13.23 \pm 0.51 in the kidney. Thus, for both $\mathrm{C}$ and $\mathrm{N}$, isotope ratios showed very little variation by tissue type $\left(<3 \%\right.$ ofor $\delta^{13} \mathrm{C}$ and $<5 \%$ ofor $\left.\delta^{15} \mathrm{~N}\right)$.

\section{Morbillivirus}

Much of the material sampled (tissue from whales \#4, 5, and 6) was in a very poor state of preservation by the time of analysis due to inadvertent defrosting of some samples during courier transportation from New Caledonia to Europe. The lung tissue from whale \#6 was tested positive for morbillivirus. We were not able to detect morbillivirus in the other tissues sampled. This may have been due to poor sample quality rather than an absence of the virus. Sequencing and phylogenetic comparisons of the virus from the Longman's beaked whale \#6 using the $\mathrm{P}$ gene fragments available in GenBank revealed that it clustered with the cetacean morbillivirus CeMV-1 lineage (black arrow, Fig. 9; following the nomenclature of Van Bressem et al. 2014). The partial $\mathrm{P}$ gene sequence obtained has been deposited in GenBank (Accession No. KR704575).

\section{Discussion}

This recent stranding of Longman's beaked whales has provided new information on several aspects of the biology of this little known species, and for an area of their distribution for which there are currently few data available (Yamada et al. 2012).

The size of this mass stranded group ( 7 animals) is consistent with that reported for atsea sightings of Indopacetus. For example, Pitman et al. (1999) found a mean group size of 18.5 animals (range 1-100), from 44 observations in the tropical Indian and Pacific Oceans, while Anderson et al. (2006) found a mean group size of 7.2 animals (range 1-40) from 32 observations in the West Indian Ocean. 
The four females (subadults and adults) stranded in New Caledonia were within the known range for females Indopacetus (5.65-6.5 m; Yamada et al. 2012, Yao et al. 2012). The adult male that died on the first day is one of the few adult males known for this species to date. It was slightly shorter than a specimen measured in China (6.08 m, Peng et al. 2009) and longer than the physically mature male measured in the Philippines $(5.73 \mathrm{~m}) .2$ As appears to be the case for many ziphiids, the two adult females were slightly larger $(618-640 \mathrm{~cm})$ than the adult male $(590 \mathrm{~cm})$. This is in contrast to many other odontocetes, where males are generally bigger than females (e.g., Jefferson et al. 2008). This is the first time that teeth from this species have been used for age estimation but if our estimates of age based on tooth GLG analyses are correct, female Indopacetus do not reach physical maturity and acquire adult coloration until they are over ca. $14 \mathrm{yr}$ of age. In contrast, both male and female Blainville's beaked whales appear to reach sexual maturity at 9 yr of age (Claridge 2013). The estimated size of the calf (ca. $300 \mathrm{~cm}$ ) suggests that it was less than a year old, based on comparisons to a neonate calf from South Africa that was $291 \mathrm{~cm}$ long (Dalebout et al. 2003).

This is only the third confirmed adult male to be examined for this species, and, to our knowledge, the first time that images of the teeth of an adult male, in and ex situ, have been published. Adult male tooth morphology and tooth position in the lower jaw are key diagnostic feature for many ziphiids (e.g., Jefferson et al. 2008). The holotype from Mackay, Queensland (Longman 1926) was considered to be "an old adult male" (Moore 1968), but as this specimen consists only of a beach cast skull and mandibles without teeth, it is difficult to be sure. Moore (1968, p. 282) examined the tooth sockets (alveoli) of the holotype which 'become progressively as shallow as $30 \mathrm{~mm}$ ' and suggested that this feature was diagnostic for Indopacetus. (The alveoli of adult male Mesoplodon spp. are deep and remain deep with age; Mead 2002a). Dalebout et al. (2003) compared the holotype with an adult female from the Republic of Maldives, and found the alveoli were very similar in length and width. This suggested that the teeth they supported were also similar, and cast doubt on the age-sex class of the holotype. Comparisons presented here add weight to the hypothesis that the holotype is indeed an adult male. The alveoli of the New Caledonia male were wider and more "worn" than those of the females (Fig. 7), as expected given the larger, more pear-shaped teeth of the male (Fig. 6), as well their likely use as weapons in aggressive encounters with conspecific males, as inferred from linear tooth rake scars (e.g., Dalebout et al. 2008). The alveoli of the holotype also appear wider and somewhat worn, though not to the extent observed in the adult male from New Caledonia (MLD, personal observation). Ultimately molecular sexing will be required to 
confirm the sex of the holotype; a difficult undertaking given the degraded nature of DNA extracted from old bones.

Little information on group composition is available for most beaked whales species as this often requires following large numbers of individually identified animals over long periods of time. In northern bottlenose whales, groups generally consist of a mix of different age-sex classes, where females form a loose network of social partners with no obvious long-term associations, while associations between males appear more stable (Gowans et al. 2001). In Blainville's beaked whales and Cuvier's beaked whales, group structure appears more similar to what we observed here for Indopacetus, with a number of females, subadults, and calves accompanied by a single mature male with erupted teeth (Baird et al. 2006, MacLeod and D'Amico 2006, McSweeney et al. 2007, Claridge 2013). That these Longman's beaked whales stranded together suggests that this species, like other social odontocetes known to mass strand, has very strong group bonds (e.g., Connor and Norris 1982, Stacey and Baird 1991).

All five stranded whales for which genetic material was obtained shared the same mtDNA control region haplotype over the $680 \mathrm{bp}$ fragment analyzed, i.e., all appear to represent the same maternal lineage. This could be due to low levels of intraspecific genetic diversity, at least for populations in the Western Tropical Pacific. Our estimates of genetic diversity for Indopacetus based on the short mtDNA fragment currently available for all specimens analyzed to date (226 bp, $\mathrm{n}=8$ animals) were also relatively low $(\pi=0.59 \%)$. Similar low levels of intraspecific diversity have been reported for many other ziphiid species (e.g., Dalebout et al. 2004, 2005, 2006, 2007, 2014; Thompson 2013). The single mtDNA haplotype observed among the stranded whales in New Caledonia could also be due to matrilineal social structure. Matrilineal social structure, and associated low mtDNA diversity, has been described for several other species of odontocetes, in particular those prone to mass stranding such as sperm whales (Physeter macrocephalus; Whitehead 1998, Mesnick 2001) and long-finned pilot whales (Globicephala melas; Oremus et al. 2013).

The stomachs of the Longman's beaked whales examined here were relatively simple and appeared to consist of only two pockets. This is in contrast to the multiple pockets and often complex stomach morphology of many other ziphiid species (Mead 1993, 2002b). The fusing of the first five cervical vertebrae (of C7 total), as observed in animals \#4 and 5, appears to be diagnostic for this species (Dalebout et al. 2003, West et al. 2013).

The stomachs of the whales we examined were empty, with the exception of plastic debris. The ingestion of this material is unlikely to be the direct cause of the stranding and death of these animals, but consuming such objects is obviously not conducive to long term good 
health. In this case, there were no signs of blockage and the gastritis was too chronic and serious to be attributed to the plastic bag which must has been ingested only recently as the advertisements printed on it were still easily readable. The generally good body condition of these whales also suggests that the plastic debris had not impaired food intake and digestion as was the case for the Longman's beaked whale recently stranded in India (Kaladharan et al. 2014). Plastic debris is one of the most pervasive pollution issues affecting the world's oceans today, causing the injury and death of large numbers of marine species through entanglement or ingestion (Allsopp et al. 2006).

The majority of beaked whales are thought to feed primarily on deep-water squid based on examination of stomach contents and stable isotope analyses (Mead 2002a). The usefulness of stable isotopes and trace elements as tracers to investigate the trophic ecology and the foraging habitat of marine mammals has been well documented (e.g., Kelly 2000). For these Longman's beaked whales, stable isotope ${ }^{13} \mathrm{C}$ and ${ }^{15} \mathrm{~N}$ values showed little variation among the different tissues analyzed suggesting that diet and foraging habitat were fairly constant over long periods of time. Similar ${ }^{13} \mathrm{C}$ and ${ }^{15} \mathrm{~N}$ signatures have been observed in other squid-eating odontocetes from this region (C. Garrigue et al., unpublished data): pygmy and dwarf sperm whales (Kogia breviceps and K. sima); short-finned pilot whales (Globicephala macrorhynchus); and pygmy killer whales (Feresa attenuata), suggesting these species forage in the same oceanic habitat $\left({ }^{13} \mathrm{C}\right)$ and share a similar trophic position $\left({ }^{15} \mathrm{~N}\right)$.

Cephalopod consumption is considered a major route of exposure to $\mathrm{Cd}$ (Bustamante et al. 1998, Lahaye et al. 2005). The elevated Cd concentrations observed here in the kidney and liver further confirm that the diet of Indopacetus is likely to be largely comprised of pelagic cephalopods, with squids probably the main component. The extensive resorption of dentine observed in the roots of the teeth of some of the whales could also be linked to elevated levels of $\mathrm{Cd}$ in the body (Luque et al. 2013). The renal concentrations were twice as high as levels reported for Atlantic white-sided dolphins (Lagenorhynchus acutus), which for these dolphins were suspected of inducing kidney damages (Gallien et al. 2001). Nevertheless, it is recognized that squid specialist species will have higher tolerance levels for $\mathrm{Cd}$ (Muirhead and Furness 1988, Jackson et al. 2007). The elevated concentrations of $\mathrm{Hg}$ and $\mathrm{Cd}$ observed here in the livers fell within the range observed in other odontocetes from this region (Bustamante et al. 2003; Garrigue et al., unpublished data). Concentrations of other elements were comparable to those found in beaked whales in other parts of the world (Law et al. 1997, 2001; Storelli et al. 1999), suggesting that mining activities in New Caledonia do not represent a significant source of contaminants for Indopacetus at this stage. 
Although the stranded animals appeared to be in relatively good condition outwardly, subsequent examination revealed substantial health issues. These included one whale with chronic gastritis - inflammation of stomach lining (\#5) and another with acute pleurisyinflammation of lung membranes (\#6). The same two animals had plastic debris in their stomachs, and the latter animal tested positive for morbillivirus. The relative thinness of the latter whale's blubber was also likely a reflection of its poor health. All these symptoms are known pathological features for morbillivirus infection (Keck et al. 2010, Rubio-Guerri et al. 2013). Immune suppression associated with morbillivirus infections can also influence mortality rates by allowing secondary bacterial infections to flourish (Guardo et al. 2005).

Morbillivirus outbreaks have been linked to mass mortality events worldwide in a number of cetacean species (Van Bressem et al. 2009). This study is the first to reveal the presence of morbillivirus infection in Longman's beaked whale in New Caledonia waters. And surprisingly, the strain of morbillivirus isolated from animal \#6 showed greater similarity to DMV strains from the Mediterranean and Atlantic Ocean and the North Sea than other strains from the Southern Hemisphere. Interestingly, our strain did not cluster with the BWMV found in a Longman's beaked whale in Hawaii in 2010 (West et al. 2013). The phylogenetic diversity of CeMV strains on published partial gene sequences or from full genome sequencing, indicates the existence of two separate lineages (Van Bressem et al. 2014). The CeMV-1 includes typical dolphin, porpoise, pilot whale and beaked whale morbillivirus strains (DMV, PMV, PWMV, and BWMV) from the Northern Hemisphere. The CeMV-2 lineage, more commonly found in the Southern Hemisphere, is highly divergent and it includes strains from Indo-Pacifique bottlenose dolphin (Tursiops aduncus) in Western Australia (Stephens et al. 2014), and a Guiana dolphin (Sotalia guianensis) in Brazil (Groch et al. 2014). While known from several different species of marine mammals in the Northern Hemisphere, DMV also circulates in the Southern Hemisphere. This strain was found in an offshore bottlenose dolphin (Tursiops truncatus) stranded on the coast of Queensland, Australia (Stone et al. 2011). Taken together the above data suggest that Australian waters could be the crossroads of circulation for both the CeMV-1 and CeMV-2 lineages. With infectious viruses such as this, transmission between animals may also be enhanced by various behaviors, such as strong group cohesion in social odontocetes (Anderson et al. 2006, Pitman 2009). Like terrestrial morbillivirus strains, the spread of CeMVs to new areas can also be facilitated by long distance migrations of diseased animals (e.g., Appel and Summers 1995). With the currently limited information on morbillivirus infection in the southwest Pacific, the discovery of this virus in New Caledonian 
waters poses some serious questions regarding its potential impact on marine mammals in this region.

To the best of our knowledge, this mass stranding of beaked whales, does not appear to have been caused by a reaction to anthropogenic noise, i.e., an "atypical" mass stranding (D'Amico et al. 2009). We have been unable to find any evidence of human activities in the greater stranding area that could have caused high levels of noise, such as seismic surveys of the sea floor or naval active sonar exercises, during the time that the stranding occurred. We are aware, however, that we cannot rule out this possibility. We were unfortunately unable to conduct the comprehensive histopathology analyses required to detect anatomical evidence of trauma often related to "atypical" mass strandings in beaked whales, such as gas-bubble lesions (Jepson et al. 2003). Overall, our detection of morbillivirus in the tissues of one of the whales, and the discovery of plastic debris in the stomachs of two of the whales, highlights the risk that contagious diseases and the increasing pollution of the oceans pose to marine mammals.

\section{Acknowledgments}

We are grateful to all the volunteers especially M. Poupon, M. Negrelo and the rangers of the southern lagoon who assisted with the stranding event on the 16th and 17th of November. We thank the recreational divers who provided video footage and photos taken during the first stranding of the $16^{\text {th }}$ of November. We also thank N. Stephens for provision as a personal communication of $\mathrm{P}$ gene partial viral sequences identified in Indo-Pacific bottlenose dolphins in Western Australia. This study was partially funded by the Observatoire de l'Environnement en Nouvelle-Calédonie (OEIL) and the Comité Consultatif Coutumier Environnemental (CCCE). We thank M. Brault-Favrou and G. Guillou from the "Analyses Isotopiques" group of LIENSs for running the stable isotope analyses. We also thank Dr C. Payri from CoReUs-IRD in Nouméa for her support to conduct the mtDNA and molecular analyses by providing access to the Plateforme du Vivant. This research was carried out under permit \# 31572012/ARR/DENV issued by the Department of the Environment, Province South, New Caledonia. CG, MO, RD and JCV collected data during stranding. JCV conducted the autopsy during the stranding event. MO conducted genetic analyses and carried out sequence aligments. CL conducted the estimation of age. PB conducted analyses on stable isotope and trace elements. GL and OK detected morbillivirus and analyse the sequence. CG designed and coordinated the study. CG, MO, JCV, PB, CL, GL, MD drafted the manuscript. All authors gave final approval for publication. 


\section{References}

Acebes, J.M.V., A.L. Bautista, T.K. Yamada, L. Dolar, and W. Perrin. 2005. Stranding of Indopacetus pacificus in Davao, Philippines. 16th Biennial Conference on the Biology of Marine Mammals, San Diego, USA, p.8

Allsopp, M., A. Walters, D. Santillo, and P. Johnston. 2006. Plastic debris in the world's oceans. Greenpeace, Amsterdam. 44 pp.

Anderson, R.C., R. Clark, P.T. Madsen, C. Johnson, J. Kiszka, and O. Breysse. 2006. Observations of Longman's beaked whales (Indopacetus pacificus) in the western Indian Ocean. Aquatic Mammals 32 (2):223-231.

Afsal, V.V., P.P. Manojkumara, K.S.S.M. Yousufa, B. Anoopa, and E. Vivekanandana. 2009. The first sighting of Longman's beaked whale, Indopacetus pacificus in the southern Bay of Bengal. Marine Biodiversity Records, 2, e133 doi:10.1017/S1755267209990510.

Azzaroli, M. L. 1968. Second specimen of Mesoplodon pacificus, the rarest living beaked whale. Monitore Zoologico Italiano (N. S.) 2(Supplement):67-79.

Barrett, T., L.K. Visser, L. Mamaev, L. Goatley, M.F. VanBressem, and A.D. Osterhaust. 1993. Dolphin and porpoise morbilliviruses are genetically distinct from phocine distemper virus. Virology 193:1010-1012.

Bustamante, P., F. Caurant, S.W. Fowler, and P. Miramand. 1998. Cephalopods as a vector for the transfer of cadmium to top marine predators in the north-east Atlantic Ocean. Science of the Total Environment 220:71-80.

Bustamante, P., C. Garrigue, L. Breau, F. Caurant, W. Dabin, J. Greaves, and R. Dodemont. 2003. Trace elements in two odontocetes species (Kogia breviceps and Globicephala macrorhynchus) stranded in New Caledonia (South Pacific). Environmental Pollution 124:263-271.

Bustamante, P., V. Lahaye, C. Durnez, C. Churlaud, and F. Caurant. 2006. Total and organic $\mathrm{Hg}$ concentrations in cephalopods from the North East Atlantic waters: influence of geographical origin and feeding ecology. Science of the Total Environment 368:585596.

Chouvelon, T., J. Spitz, Y. Cherel, F. Caurant, R. Sirmel, P. Mèndez-Fernandez, and P. Bustamante. 2011. Species and ontogenic-related differences in $\delta^{13} \mathrm{C}$ and $\delta^{15} \mathrm{~N}$ values and $\mathrm{Hg}$ and $\mathrm{Cd}$ concentrations of cephalopods. Marine Ecology Progress Series 433:107-120.

D'Amico, A., R.C. Gisiner, D.R. Ketten, J.A. Hammock, C. Johnson, P.L. Tyack, and J.G. Mead. 2009. Beaked whale strandings and naval exercises. Aquatic Mammals, 35(4):452-472.

Dalebout, M. L. 2002. Species identity, genetic diversity and molecular systematic relationships among the Ziphiidae (beaked whales). PhD thesis, School of Biological Sciences, University of Auckland, Auckland, New Zealand. pp. 384.

Dalebout, M.L., C.S. Baker, R.C. Anderson, P.B. Best, V.G. Cockcroft, H.L. Hinsz, V. Peddemors, and R.L. Pitman. 2003. Appearance, distribution, and genetic distinctiveness of Longman's beaked whale, Indopacetus pacificus. Marine Mammal Science 19:421-461.

Dalebout, M.L., C.S. Baker, J.G. Mead, V.G. Cockcroft, and T.K. Yamada. 2004. A comprehensive and validated molecular taxonomy of beaked whales, Family Ziphiidae. Journal of Heredity 95:459-473.

Dalebout, M.L., K.M. Robertson, A. Frantzis, D. Engelhaupt, A.A. Mignucci-Giannoni, R.J. Rosario-Delestre, and C.S. Baker. 2005. Worldwide structure of mtDNA diversity 
among Cuvier's beaked whales (Ziphius cavirostris): implications for threatened populations. Molecular Ecology 14:3353-3371.

Dalebout, M.L., D.E. Ruzzante, H. Whitehead, and N.I. Øien. 2006. Nuclear and mitochondrial markers reveal distinctiveness of a small population of bottlenose whales (Hyperoodon ampulatus) in the western North Atlantic. Molecular Ecology 15:3115-3129.

Dalebout, M. L., C.S. Baker, D. Steel, K.M. Robertson, S.J. Chivers, W.F. Perrin, and D. Schofield. 2007. A divergent mtDNA lineage among Mesoplodon beaked whales: molecular evidence for a new whale in the Tropical Pacific? Marine Mammal Science, 23(4):954-966.

Dalebout, M. L., D. Steel, and C.S. Baker. 2008. Phylogeny of the beaked whale genus Mesoplodon (Ziphiidae: Cetacea) revealed by nuclear introns: implications for the evolution of male tusks. Systematic Biology 57(6):857-875.

Dalebout, M. L., C.S. Baker, D. Steel, K. Thompson, K. Robertson, S.J. Chivers, and T.K. Yamada. 2014. Resurrection of Mesoplodon hotaula Deraniyagala 1963: a new species of beaked whale in the tropical Indo-Pacific. Marine Mammal Science. Epub. 5 February 2014.

De Niro, M.J., and S. Epstein. 1977. Mechanism of carbon fractionation associated with lipid synthesis. Science 197:261-263.

Drummond, A.J., B. Ashton, M. Cheung, et al. 2009. Geneious v4.8, Available from http://www.geneious.com/.

do Sul, J. A. I., and M.F. Costa. 2014. The present and future of microplastic pollution in the marine environment. Environmental Pollution 185:352-364.

Edgar, R.C. 2004. MUSCLE: a multiple sequence alignment method with reduced time and space complexity. BMC Bioinformatics 5:113.

Excoffier, L., and H.E.L. Lischer. 2010. Arlequin suite ver 3.5: A new series of programs to perform population genetics analyses under Linux and Windows. Molecular Ecology Resources 10:564-567.

Gallien, I., F. Caurant, M. Bordes, P. Bustamante, P. Miramand, B. Fernandez, N. Quellard, and P. Babin. 2001. Cadmium-containing granules in kidney tissue of the Atlantic white-sided dolphin (Lagenorhyncus acutus) off the Faroe Islands. Comparative Biochemistry and Physiology Part C: Pharmacology, Toxicology and Endocrinology 130:389-395.

Garrigue, C., and M. Poupon. 2013. Guide d'identification des mammifères marins de Nouvelle-Calédonie. Opération Cétacés 128p

Gascuel, O. 1997. BIONJ: an improved version of the NJ algorithm based on a simple model of sequence data. Molecular Biology Evolution 14(7):685-95.

Gilson, A., M. Syvanen, K. Levine, and J. Banks. 1998. Deer gender determination by polymerase chain reaction: validation study and application to tissues, bloodstains, and hair forensic samples from California. California Fish and Game 84:159-169.

Gowans, S., H. Whitehead, S.K. and Hooker. 2001. Social organization in northern bottlenose whales (Hyperoodon ampullatus): not driven by deep water foraging? Animal Behaviour, 62, 369-377.

Groch K.R., A.C. Colosio, M.C. Marcondes, D. Zucca, J. Díaz-Delgado, C. Niemeyer, J. Marigo, P.E. Brandão, A. Fernández, J. Luiz Catão-Dias. 2014. Novel cetacean morbillivirus in Guiana dolphin, Brazil. Emerg Infect Dis. 20(3):511-3.

Guardo, G. D., G. Marruchella, U. Agrimi, and S. Kennedy. 2005. Morbillivirus infections in aquatic mammals: a brief overview. Journal of Veterinary Medicine Series A, 52: 8893.

von Haast, J. 1876. On a new ziphioid whale. Proceedings of the Zoological Society of London, 4 January, 7-13. [Type description of Mesoplodon grayi]. 
Jefferson, T. A., S. Leatherwood, and M.A. Webber. 2008. FAO Species Identification Guide: Marine Mammals of the World. Rome: United States Environment Programme; Food and Agriculture Organization of the United Nations (FAO).

Jepson, P.D., M. Arbelo, R. Deaville, I.A. Patterson, P. Castro, J.R. Baker, E. Degollada, H.M. Ross, P. Herraez, A.M. Pocknell, F. Rodriguez, F.E. Howie, A. Espinosa, R.J. Reid, J.R. Jaber, V. Martin, A.A. Cunningham, and A. Fernandez. 2003. Gas-bubble lesions in stranded cetaceans. Nature 425 (9 October 2003):575-576.

Kaladharan, P., P.K. Asokan, K. Mohammed Koya, and H.M. Bhint. 2014. Plastic debris in the stomach of a Longman's Beaked Whale, Indopacetus pacificus (Longman, 1926) stranded off Sutrapada, Veraval, Saurashtra coast, India. Marine Biological Association of India 56(2):92-94.

Keck, N., O. Kwiatek, F. Dhermain, F. Dupraz, H. Boulet, C. Danes, C. Laprie, A. Perrin, J. Godenir, and L. Micout. 2010. Resurgence of Morbillivirus infection in Mediterranean dolphins off the French coast. Veterinary Record 166:654-655.

Kelly, J. F. 2000. Stable isotopes of carbon and nitrogen in the study of avian and mammalian trophic ecology. Canadian Journal of Zoology 78(1):1-27.

Lahaye, V., P. Bustamante, J. Spitz, W. Dabin, K. Das, G.J. Pierce, and F. Caurant. 2005. Longterm dietary segregation of common dolphins Delphinus delphis in the Bay of Biscay, determined using cadmium as an ecological tracer. Marine Ecology Progress Series 305:275-285.

Landrau-Giovannetti, N., L. Brown, R. Henríquez, L. L. Archer, G. Cortés-Hinojosa, P. J. Duignan, O. Nielsen, T. K. Rowles, J. Saliki, N. Stephens, J. Wang, K.West, J. F.X. Wellehan, and T. D. Waltzek. Phylogenic diversity of cetacean morbillivirus. In Proceedings of the Fifth Florida Marine Mammal Health Conference June 2-4, 2015. Gainesville, Florida

Law K.L. and Thompson R.C. 2014. Microplastics in the seas. Science 345:144-145.

Law, R.J., C.R. Allchin, B.R. Jones, P.D. Jepson, J.R. Baker, and C.J.H. Spurrier. 1997. Metals and organochlorines in tissues of a Blainville's beaked whale (Mesoplodon densirostris) and a killer whale (Orcinus orca) stranded in the United Kingdom. Marine Pollution Bulletin 34 (3):208-212.

Law, R.J., M.E. Bennett, S.J. Blake, C.R. Allchin, B.R. Jones, and C.J.H. Spurrier. 2001. Metals and organochlorines in pelagic cetaceans stranded on the coasts of England and Wales. Marine Pollution Bulletin 42 (6):522-526.

Lockyer, C.H. 1993. A report on patterns of deposition of dentine and cement in teeth of pilot whales, genus Globicephala. Reports of the International Whaling Commission (Special Issue 14):137-161.

Lockyer, C.H. and G.T. Braulik. 2014. An evaluation of age estimation using teeth from South Asian River dolphins (Platanistidae). NAMMCO Scientific Publications, doi: http://dx.doi.org/10.7557/3.3268

Longman, H.A. 1926. New records of Cetacea, with a list of Queensland species. Memoirs of the Queensland Museum 8:226-278. [Type description of Indopacetus [Mesoplodon pacificus].

MacLeod, C. D., and A. D'Amico. 2006. A review of beaked whale behaviour and ecology in relation to assessing and mitigating impacts of anthropogenic noise. Journal of Cetacean Research and Management 7(3):211-221.

Mead, J. G. 1993. The systematic importance of stomach anatomy in beaked whales. IBI Reports 4:75-86.

Mead, J. G. 2002a. Beaked whales, overview. Pages 81-84 in W. F. Perrin, B. Wursig, and J. G. M. Thewissen eds. Encyclopedia of Marine Mammals. San Diego: Academic Press. 
Mead, J. G. 2002b. Gastrointestinal Tract. Pages 488-495 in W. F. Perrin, B. Wursig, and J. G. M. Thewissen eds. Encyclopedia of Marine Mammals. San Diego: Academic Press.

McSweeney, D. J., R.W. Baird, and S.D. Mahaffy. 2007. Site fidelity, associations, and movements of Cuvier's (Ziphius cavirostris) and Blainville's (Mesoplodon densirostris) beaked whales off the island of Hawai'i. Marine Mammal Science 23(3): 666-687.

Miller, C.A. 2007. Current State of Knowledge of Cetacean Threats, Diversity and Habitats in the Pacific Islands Region. WDCS Australasia Inc.

Moore, J.C. 1968. Relationships among the living genera of beaked whales. Fieldiana Zoology 53:209-298.

Morzer Bruyns, W.F.J. 1971. Field Guide of Whales and Dolphins. Amsterdam: C.A. Mees.

Nei, M. 1987. Molecular evolutionary genetics Columbia University Press, New York.

Oremus, M., M.M. Poole, D. Steel, and C.S. Baker. 2007. Isolation and interchange among insular spinner dolphin communities in the South Pacific revealed by individual identification and genetic diversity. Marine Ecology Progress Series 336:275-289.

Oremus, M., R. Gales, H. Kettles, and C.S. Baker. 2013. Genetic evidence of multiple matrilines and spatial disruption of kinship bonds in mass strandings of long-finned pilot whales, Globicephala melas. Journal of Heredity. 104:301-11.

Peng, Y.Y.W., Z. Qian, H. Shen, and H. Wang. 2009. Description of a new record species of whale from chinese coastal waters. China Journal of Marine Sciences, 27(4):117-120.

Perrin, W. F, and Myrick, A. C, Jr. eds. 1980. "Age Determination of Toothed Whales and Sirenians." International Whaling Commission, Cambridge.

Pitman, R. L., D.M. Palacios, P.L.R. Brennan, K.C. Balcomb, III, and T. Miyashita. 1999. Sightings and possible identity of a bottlenose whale in the tropical Indo-Pacific: Indopacetus pacificus? Marine Mammal Science 15:531-549.

Pitman R.L. 2009. Indo-Pacific beaked whale - Indopacetus pacificus. In: Encyclopedia of Marine Mammals, 2nd Ed. (Perrin WF, Würsig B, Thewissen JGM, eds.) Academic Press, Amsterdam, pp. 600-602.

Rubio-Guerri, C., M. Melero, F. Esperon, E. Belliere, M. Arbelo, J. Crespo, E. Sierra, D. Garcia-Parraga, and J. Sanchez-Vizcaino. 2013. Unusual striped dolphin mass mortality episode related to cetacean morbillivirus in the Spanish Mediterranean Sea. BMC Veterinary Research 9(1):106.

Ross, H.A., G.M. Lento, M.L. Dalebout, M. Goode, G. Ewing, P. McLaren, A.G. Rodrigo, S. Lavery, and C.S. Baker. 2003. DNA Surveillance: Web-based molecular identification of whales, dolphins and porpoises. Journal of Heredity 94:111-114.

Saitou N., and M. Nei. 1987. The neighbor-joining method: A new method for reconstructing phylogenetic trees. Molecular Biology and Evolution 4(4):406-25.

Sierra, E., D. Zucca, M. Arbelo, N. García-Álvarez, M. Andrada, S. Déniz, and A. Fernández. 2014. Fatal systemic morbillivirus infection in bottlenose dolphin, Canary Islands, Spain. Emerging Infectious Disease 20:269-71.

Stephens N., P.J. Duignan, J. Wang, J. Bingham, H. Finn, L. Bejder, A.P. Patterson, C. Holyoake. 2014. Cetacean morbillivirus in coastal Indo-Pacific bottlenose dolphins, Western Australia. Emerg Infect Dis. 20(4):666-670.

Stone, B.M., D.J. Blyde, J.T. Saliki, U. Blas-Machado, J. Bingham, A. Hyatt, J. Payne, S. and Crameri. 2011. Fatal cetacean morbillivirus infection in an Australian offshore bottlenose dolphin (Tursiops truncatus). Australian veterinary Journal 89 (11):452-457.

Storelli, M.M., N. Zizzo, and G.O. Marcotrigiano. 1999. Heavy metals and methylmercury in tissues of Risso's dolphin (Grampus griseus) and Cuvier's beaked whale (Ziphius cavirostris) stranded in Italy (South Adriatic Sea). Bulletin of Environmental Contamination and Toxicology 63:703-710. 
Tamura, K., G. Stecher, D. Peterson, A. Filipski, and S. Kumar. 2013. Mega6: molecular evolutionary genetics analysis version 6.0. Molecular biology and evolution 30, 12: 2725-2729.

Van Bressem, M.F., J.A. Raga, G. Di Guardo, P.D. Jepson, P.J. Duignan, U. Siebert, T. Barrett, M.C. Santos, I.B. Moreno, and S. Siciliano. 2009. Emerging infectious diseases in cetaceans worldwide and the possible role of environmental stressors. Diseases of Aquatic Organisms 86(2):143-157.

Van Bressem M.F., P.J. Duignan, A. Banyard, M. Barbieri, K.M. Colegrove, S. De Guise, G. Di Guardo, A. Dobson, M. Domingo, D. Fauquier, A. Fernandez, T. Goldstein, B. Grenfell, K.R. Groch, F. Gulland, B.A. Jensen, P.D. Jepson, A. Hall, T. Kuiken, S. Mazzariol, S.E. Morris, O. Nielsen, J.A. Raga, T.K. Rowles, J. Saliki, E. Sierra, N. Stephens, B. Stone, I. Tomo, J. Wang, T. Waltzek, J.F. Wellehan. 2014. Cetacean morbillivirus: current knowledge and future directions. Viruses. 22;6(12):5145-5181.

West, K.L., S. Sanchez, D. Rotstein, K.M. Robertson, S. Dennison, G. Levine, N. Davis, D. Schofield, C.W. Potter, and B. Jensen. 2013. A Longman's beaked whale (Indopacetus pacificus) strands in Maui, Hawaii, with first case of morbillivirus in the central Pacific. Marine Mammal Science 29:767-776.

Whitehead, H. 1998. Cultural selection and genetic diversity in matrilineal whales. Science 282:1708-1711.

Yamada, T.K., Y. Tajima, A. Yatabe, R. Pitman, and R.L. Jr Brownell. 2012. Review of current knowledge on Indopacetus pacificus including identification of knowledge gaps and suggestions for future research. Report to the Scientific Committee of the International Whaling Commission, SC/64/SM/26. Available from the International Whaling Commission, Cambridge UK.

Yang W.C., V.F. Pang, C.R. Jeng, L.S. Chou, L.L. Chueh. 2006. Morbilliviral infection in a pygmy sperm whale (Kogia breviceps) from Taiwanese waters. Vet Microbiol. 25;116(1-3):69-76.

Yao, C.J., W.C. Yang, Y.J. Chen, J.T. Lin, R.L. Jr Brownell, and L.S. Chou. 2012. Two Longman's beaked whales (Indopacetus pacificus) from Taiwan. Report to the Scientific Committee of the International Whaling Commission, SC/64/SM/32. Available from the International Whaling Commission, Cambridge UK. 
Table 1. Summary of stranded Longman's beaked whales and data collected. EM - external measurements, LKSM, - liver, kidney, spleen and muscle for trace element, stable isotope analyses and morbillivirus search; Sk - skin for genetic analysis.

\begin{tabular}{|c|c|c|c|c|c|c|c|}
\hline Specimen No. & Sex, age class & $\begin{array}{c}\text { Total length, TL } \\
(\mathrm{cm})\end{array}$ & $\begin{array}{c}\text { Success of } \\
\text { refloating after } \\
\text { first stranding, } \\
16 \text { Nov } 2013\end{array}$ & $\begin{array}{c}\text { Success of } \\
\text { refloating after } \\
\text { second stranding, } \\
17 \text { Nov } 2013\end{array}$ & Date examined & $\begin{array}{l}\text { Data and samples } \\
\text { collected }\end{array}$ & Osteological materia \\
\hline$\# 1$ & $\mathrm{~F}$, adult & 640 & $\mathrm{Y}$ & $\begin{array}{c}\text { Not observed } \\
\text { again }\end{array}$ & 16 Nov 2013 & EM, Sk & - \\
\hline$\# 2$ & M, adult & 590 & $\mathrm{~N}$ & - & 16 Nov 2013 & $\mathrm{EM}, \mathrm{Sk}$ & Teeth only \\
\hline \#3 & $\mathrm{F}$, calf & c. 300 & $\mathrm{Y}$ & $\begin{array}{c}\text { Not observed } \\
\text { again }\end{array}$ & 16 Nov 2013 & - & - \\
\hline \#A & F, subadult & 564 & $\mathrm{Y}$ & $\mathrm{N}$ & 17 Nov 2013 & EM, LKSM, Sk & $\begin{array}{l}\text { Cranium, mandible, } \\
\text { teeth, cervical } \\
\text { vertebrae }\end{array}$ \\
\hline \#B & F, subadult & 590 & $\mathrm{Y}$ & $\mathrm{N}$ & 17 Nov 2013 & EM, LKSM, Sk & $\begin{array}{l}\text { Cranium, mandible, } \\
\text { teeth, cervical } \\
\text { vertebrae }\end{array}$ \\
\hline \#C & $\mathrm{F}$, adult & 618 & Y & $\mathrm{N}$ & 17 Nov 2013 & EM, LKSM, Sk & Teeth only \\
\hline - & $?$ & & $\mathrm{Y}$ & $\begin{array}{c}\text { Not observed } \\
\text { again }\end{array}$ & Not examined & - & - \\
\hline
\end{tabular}


Table 2. Longman's beaked whale mtDNA control region sequences available in Genbank used for comparisons with the whales from New Caledonia.

\begin{tabular}{lllll}
\hline Specimen & GenBank & Sequence & Stranding Location & Source \\
& Accession & length (bp) & & \\
& No. & & & \\
\hline QM-J2016 & AY162435 & 240 & Australia (holotype) & (Dalebout et al. 2003) \\
MZUF1956 & AY162436 & 408 & Somalia & (Dalebout et al. 2003) \\
PEM292 & AY162437 & 295 & South Africa & (Dalebout et al. 2003) \\
PEM1960 & AY162438 & 295 & South Africa & (Dalebout et al. 2003) \\
- & AY162439 & 226 & Maldives & (Dalebout et al. 2003) \\
M33006 & AB572012 & 460 & Japan & (Kitamura et al. 2013) \\
USNM 593534 & - & 400 & Hawai'i & (West et al. 2013) \\
\hline
\end{tabular}


Table 3. External measurements (in $\mathrm{cm}$ ) of the six specimens of Longman's beaked whales stranded in New Caledonia (na: not available).

\begin{tabular}{|c|c|c|c|c|c|c|c|c|c|c|}
\hline Number of the stranded animal & $\# 1$ & $\# 2$ & & $\# 3$ & $\# \mathrm{~A}$ & & \#B & & $\# \mathrm{C}$ & \\
\hline \multirow[t]{2}{*}{ Sex } & $\mathrm{F}$ & $\mathrm{M}$ & & $\mathrm{F}$ & $\mathrm{F}$ & & $\mathrm{F}$ & & $\mathrm{F}$ & \\
\hline & Adult $\% \mathrm{TL}$ & Adult & $\% \mathrm{TL}$ & Calf & Adult & $\% \mathrm{TL}$ & Adult & $\% \mathrm{TL}$ & Adult & $\% \mathrm{TL}$ \\
\hline 1. Total length (TL) & 640 & 590 & & \pm 300 & 564 & & 590 & & 618 & \\
\hline 2. Beak tip to center of eye & na & na & & na & 92 & 16 & 99 & 17 & 99 & 16 \\
\hline 3. Beak tip to center of blowhole & na & na & & na & 90 & 16 & 95 & 16 & 93 & 15 \\
\hline 4. Beak tip to angle of mouth & na & 64 & 11 & na & 60 & 11 & 63 & 11 & 57 & 9 \\
\hline 5. Beak tip to anterior insertion of pectoral fin & na & na & & na & 137 & 24 & 140 & 24 & 145 & 23 \\
\hline 6. Beak tip to anterior insertion of dorsal fin & na & 358 & 61 & na & na & & na & & na & \\
\hline 7. Beak tip to the tip of the dorsal fin & na & 402 & 68 & na & 350 & 62 & 320 & 54 & na & \\
\hline 8. Beak tip to center of the genital slit & na & na & & na & 410 & 73 & 427 & 72 & 436 & 71 \\
\hline 9. Length of the genital slit & na & na & & na & 44 & 8 & 53 & 9 & 53 & 9 \\
\hline 10. Pectoral fin length: anterior insertion to the tip & na & 50 & 8 & na & 50 & 9 & 57 & 10 & 60 & 10 \\
\hline 11. Length of mammary slits & na & na & & na & 10 & 2 & 9.5 & 2 & 13 & 2 \\
\hline 12. Projection of the lower jaw beyond rostrum tip & na & 4 & 1 & na & 7 & 1 & 4 & 1 & 2 & 0.3 \\
\hline
\end{tabular}


13. Width of the blowhole

14. Pectoral fin width, maximum

15. Height of the dorsal fin

16. Fluke width

17. Fluke depth

18. Length of the dorsal base

19. Girth at axilla

20. Lateral blubber thickness

\begin{tabular}{|c|c|c|c|c|c|c|c|c|}
\hline na & na & & na & 16 & 3 & 16.5 & 3 & 16 \\
\hline na & na & & na & 15 & 3 & 16 & 3 & 17 \\
\hline 34 & 31 & 5 & na & 27 & 5 & 31 & 5 & 35 \\
\hline na & 150 & 25 & na & 130 & 23 & 128 & 22 & 142 \\
\hline na & na & & na & 44 & 8 & 43 & 7 & 43 \\
\hline 52 & 44 & 7 & na & na & & na & & na \\
\hline na & 300 & 51 & na & 260 & 46 & 266 & 45 & 266 \\
\hline$a$ & na & & na & 3.1 & & 3.8 & & 2.3 \\
\hline
\end{tabular}


Table 4. Age estimates for four of the whales based on the examination of dentinal and cementum Growth Layer Groups (GLGs) under two different treatments. See text for details. One GLG was assumed to be equal to one year. Addition symbol (+) indicates that more GLGs were present, but were too indistinct to be counted. Multiple + symbols reflect relative amount of indistinct GLGs. See Table Footnotes for Comments.

\begin{tabular}{|c|c|c|c|c|c|}
\hline \multirow{2}{*}{$\begin{array}{l}\text { Specimen } \\
\text { number }\end{array}$} & \multirow{2}{*}{$\begin{array}{l}\text { Age-sex } \\
\text { class }\end{array}$} & \multirow[t]{2}{*}{ Treatment } & \multicolumn{2}{|c|}{ No. of GLGs observed } & \multirow{2}{*}{$\begin{array}{l}\text { Overall Age } \\
\text { Estimate }\end{array}$} \\
\hline & & & Dentine & Cementum & \\
\hline \multirow[t]{2}{*}{$\# 2^{\mathrm{a}}$} & Adult M & unstained & $7+++$ & ca. 24 & $24-25 y r s$ \\
\hline & & stained & ca. 20 & ca. $23,26,25$ & \\
\hline \multirow[t]{2}{*}{$\# A^{b}$} & Subadult F & unstained & 8 & $5++$ & $8-9$ yrs \\
\hline & & stained & $9-12$ & $8+$ & \\
\hline \multirow[t]{2}{*}{$\# B^{c}$} & Subadult F & unstained & $8++$ & 14 & $13-14 \mathrm{yrs}$ \\
\hline & & stained & ca. $12+$ & $10+, 13,18$ & \\
\hline \multirow[t]{2}{*}{$\# \mathrm{C}^{\mathrm{d}}$} & Adult F & unstained & $12++$ & $20-22$ & $21-22 \mathrm{yrs}$ \\
\hline & & stained & no GLGs visible & $19,21-23$ & \\
\hline
\end{tabular}

${ }^{\mathrm{a}}$ Crown worn down such that some GLGs may be missing. Dentinal resorption in root.

${ }^{\mathrm{b}}$ The presence of pulp stones interfered with the GLG pattern in the dentine such that it was difficult to count at the base. Cement poorly stained and ill-defined. Dentinal resorption or decay in root.

${ }^{\mathrm{c}}$ GLGs have poor definition, including double laminae. Dentinal resorption or decay in root.

${ }^{\mathrm{d}}$ No dentinal resorption in root. 
Table 5. Element trace concentrations $(\mu \mathrm{g} / \mathrm{gdw})$ and stable isotope ratios $(\%)$ of carbon $\left(\delta^{13} \mathrm{C}\right)$ and nitrogen $\left(\delta^{15} \mathrm{~N}\right)$ in tissues and organs of the Longman's beaked whales. Bold font highlights elevated levels of various key heavy metals.

\begin{tabular}{|c|c|c|c|c|c|c|c|c|c|c|c|c|}
\hline \multirow{2}{*}{$\begin{array}{r}\text { Tissue type } \\
\text { Specimen }\end{array}$} & \multicolumn{4}{|c|}{ Muscle } & \multicolumn{4}{|c|}{ Kidney } & \multicolumn{4}{|c|}{ Liver } \\
\hline & \#A & \#B & $\# \mathrm{C}$ & Mean \pm SD & $\# \mathrm{~A}$ & \#B & \#C & Mean \pm SD & $\# \mathrm{~A}$ & \#B & $\# \mathrm{C}$ & Mean \pm SD \\
\hline \multicolumn{13}{|c|}{ Trace elements } \\
\hline $\mathrm{Ag}$ & $<0.5$ & $<0.5$ & $<0.5$ & - & $<0.5$ & 1.89 & 6.92 & $4.40 \pm 3.60$ & 1.57 & 2.25 & 2.51 & $2.11 \pm 0.49$ \\
\hline As & 2.5 & 2.6 & 3.8 & $3.0 \pm 0.7$ & 2.3 & 3.0 & 19.3 & $8.2 \pm 9.6$ & 18.2 & 24.3 & 23.2 & $21.9 \pm 3.3$ \\
\hline $\mathrm{Cd}$ & 0.22 & 0.30 & 0.84 & $0.45 \pm 0.34$ & 216 & 223 & 146 & $195 \pm 43$ & 97 & 142 & 169 & $136 \pm 36$ \\
\hline Co & $<0.20$ & $<0.20$ & $<0.20$ & - & 0.27 & $<0.20$ & 0.23 & $0.25 \pm 0.03$ & 0.34 & 0.37 & 0.24 & $0.32 \pm 0.07$ \\
\hline $\mathrm{Cr}$ & 0.20 & 0.20 & 0.34 & $0.25 \pm 0.08$ & 1.34 & 0.20 & 0.13 & $0.56 \pm 0.68$ & 0.13 & 0.20 & 0.15 & $0.16 \pm 0.04$ \\
\hline $\mathrm{Cu}$ & 2.2 & 2.3 & 2.3 & $2.3 \pm 0.1$ & 7.7 & 6.8 & 11.4 & $8.6 \pm 2.4$ & 10.1 & 12.7 & 9.9 & $10.9 \pm 1.6$ \\
\hline $\mathrm{Fe}$ & 761 & 764 & 919 & $814 \pm 90$ & 941 & 637 & 764 & $781 \pm 153$ & 1525 & 1422 & 924 & $1290 \pm 321$ \\
\hline $\mathrm{Hg}$ & 10.5 & 13.9 & 57.3 & $27.2 \pm 26.1$ & 128 & 12 & 620 & $253 \pm 323$ & 131 & 180 & 800 & $370 \pm 373$ \\
\hline $\mathrm{Mn}$ & 0.3 & 0.31 & 0.47 & $0.36 \pm 0.10$ & 1.8 & 1.1 & 8.3 & $3.7 \pm 4.0$ & 5.3 & 6.0 & 8.3 & $6.5 \pm 1.6$ \\
\hline $\mathrm{Ni}$ & $<0.2$ & $<0.2$ & $<0.2$ & - & 1.59 & $<0.2$ & 0.43 & $1.01 \pm 0.82$ & $<0.2$ & $<0.2$ & $<0.2$ & - \\
\hline $\mathrm{Pb}$ & $<1$ & $<1$ & $<1$ & - & $<1$ & $<1$ & $<1$ & - & $<1$ & $<1$ & $<1$ & \\
\hline $\mathrm{Se}$ & 2.1 & 3.2 & 22.9 & $9.4 \pm 11.7$ & 15.3 & 10.0 & 346 & $124 \pm 193$ & 57.7 & 103 & 278 & $146 \pm 117$ \\
\hline $\mathrm{V}$ & $<0.5$ & $<0.5$ & $<0.5$ & - & $<0.5$ & $<0.5$ & $<0.5$ & - & $<0.5$ & $<0.5$ & $<0.5$ & - \\
\hline $\mathrm{Zn}$ & 33 & 30 & 41 & $35 \pm 6$ & 102 & 81 & 169 & $117 \pm 46$ & 161 & 168 & 181 & $170 \pm 10$ \\
\hline \multicolumn{13}{|c|}{ Stable isotopes } \\
\hline${ }^{13} \mathrm{C}$ & -16.37 & -16.02 & -16.27 & $-16.22 \pm 0.18$ & - & -16.38 & -17.15 & $-16.99 \pm 0.55$ & -17.02 & -16.74 & -16.90 & $-16.89 \pm 0.14$ \\
\hline${ }^{15} \mathrm{~N}$ & 12.46 & 13.26 & 12.76 & $13.33 \pm 0.33$ & 13.26 & 13.73 & 12.71 & $13.23 \pm 0.51$ & 13.06 & 13.77 & 12.60 & $13.14 \pm 0.59$ \\
\hline
\end{tabular}




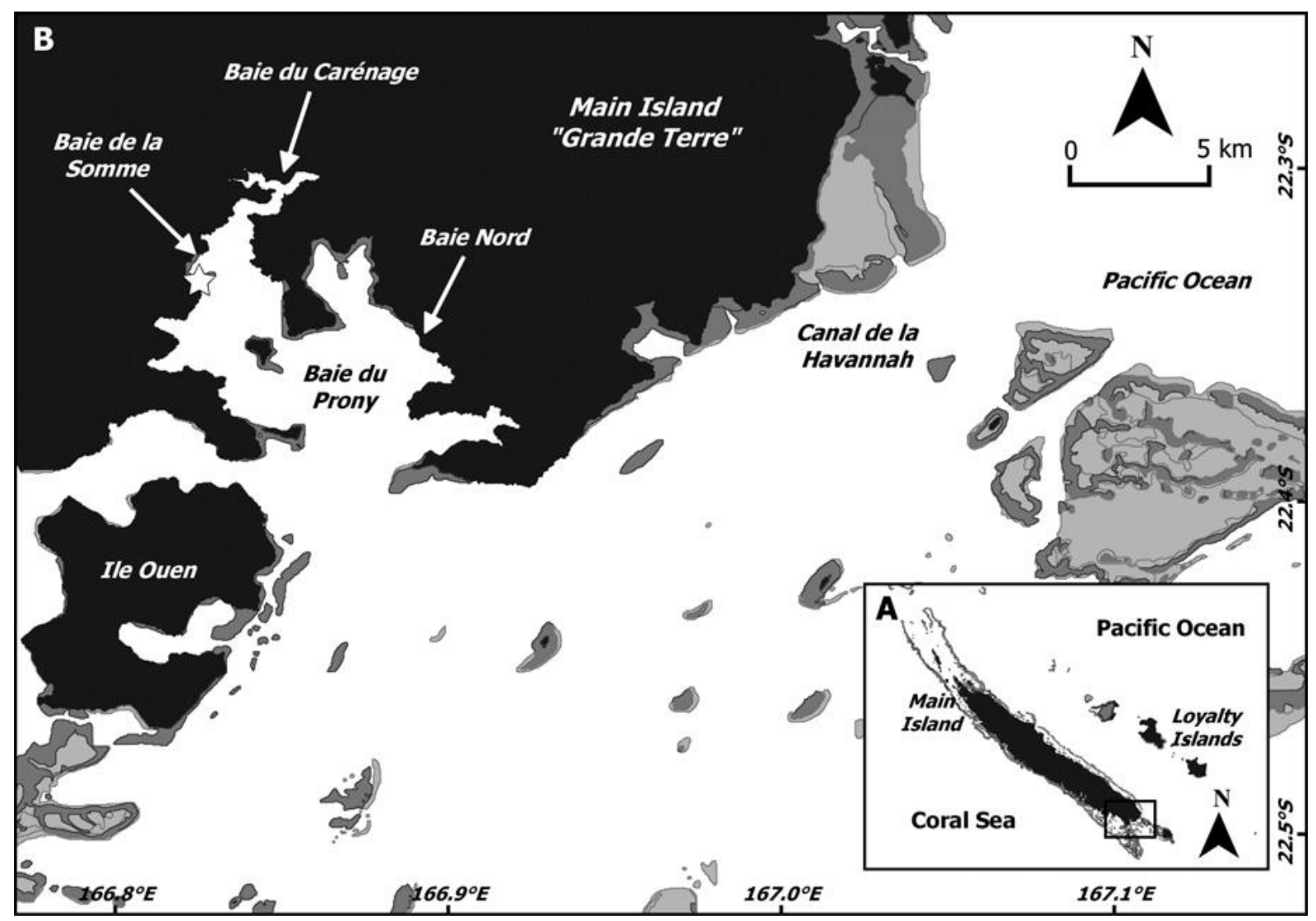

Figure 1. A, The main island of New Caledonia showing the delineation of its great lagoon. B, Detailed view of the Baie de Prony area. Star-mark indicates the location of Baie de la Somme where the mass stranding of Indopacetus occurred. 


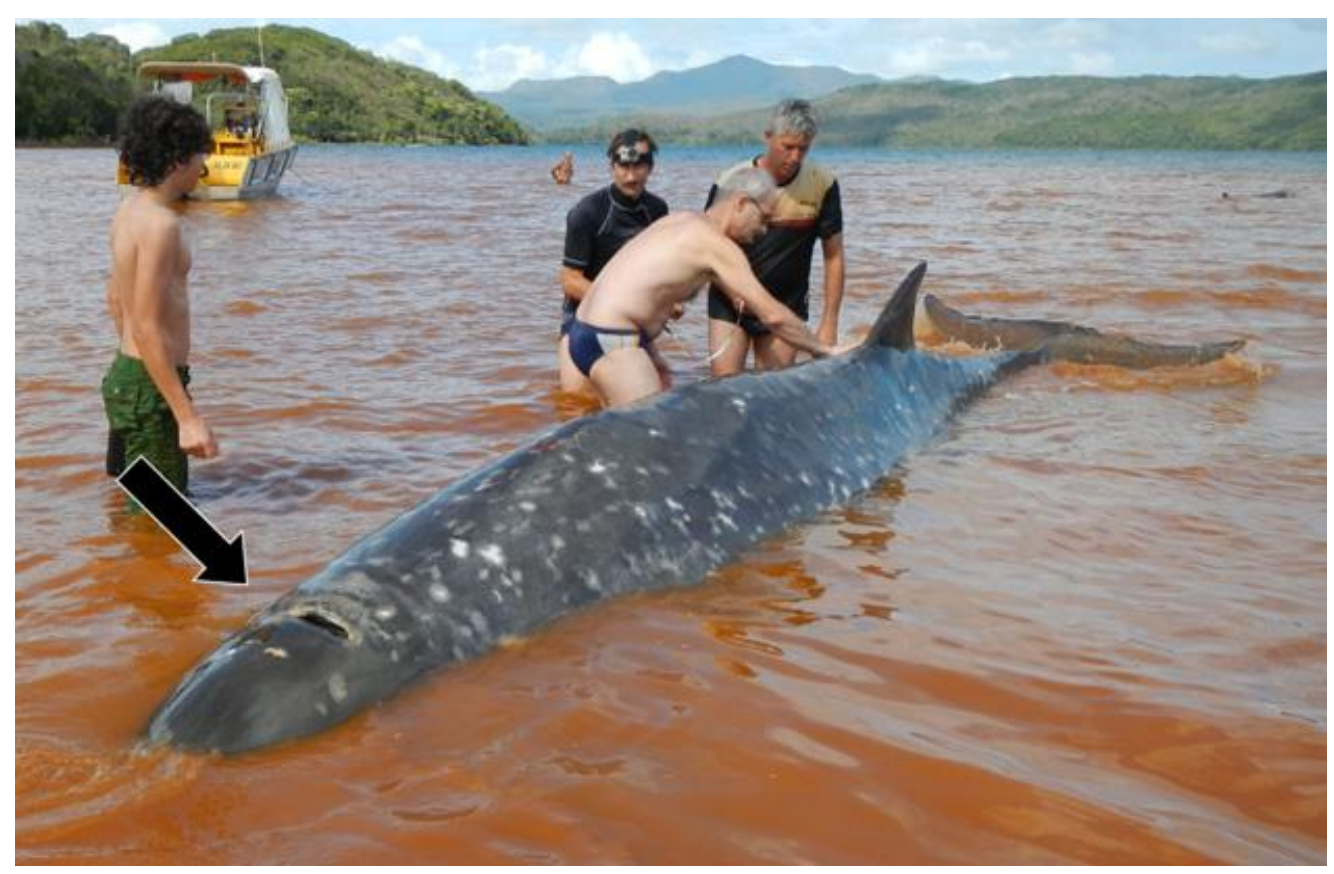

Figure 2. Adult female (\#1, $690 \mathrm{~cm}$ ) showing dorsal coloration, speckled patterning due to white cookie-cutter shark scars, and the shape of the dorsal fin and tail flukes. Arrow indicates position of the large slit-like blowhole. Photocredit: E. Rambaud. 

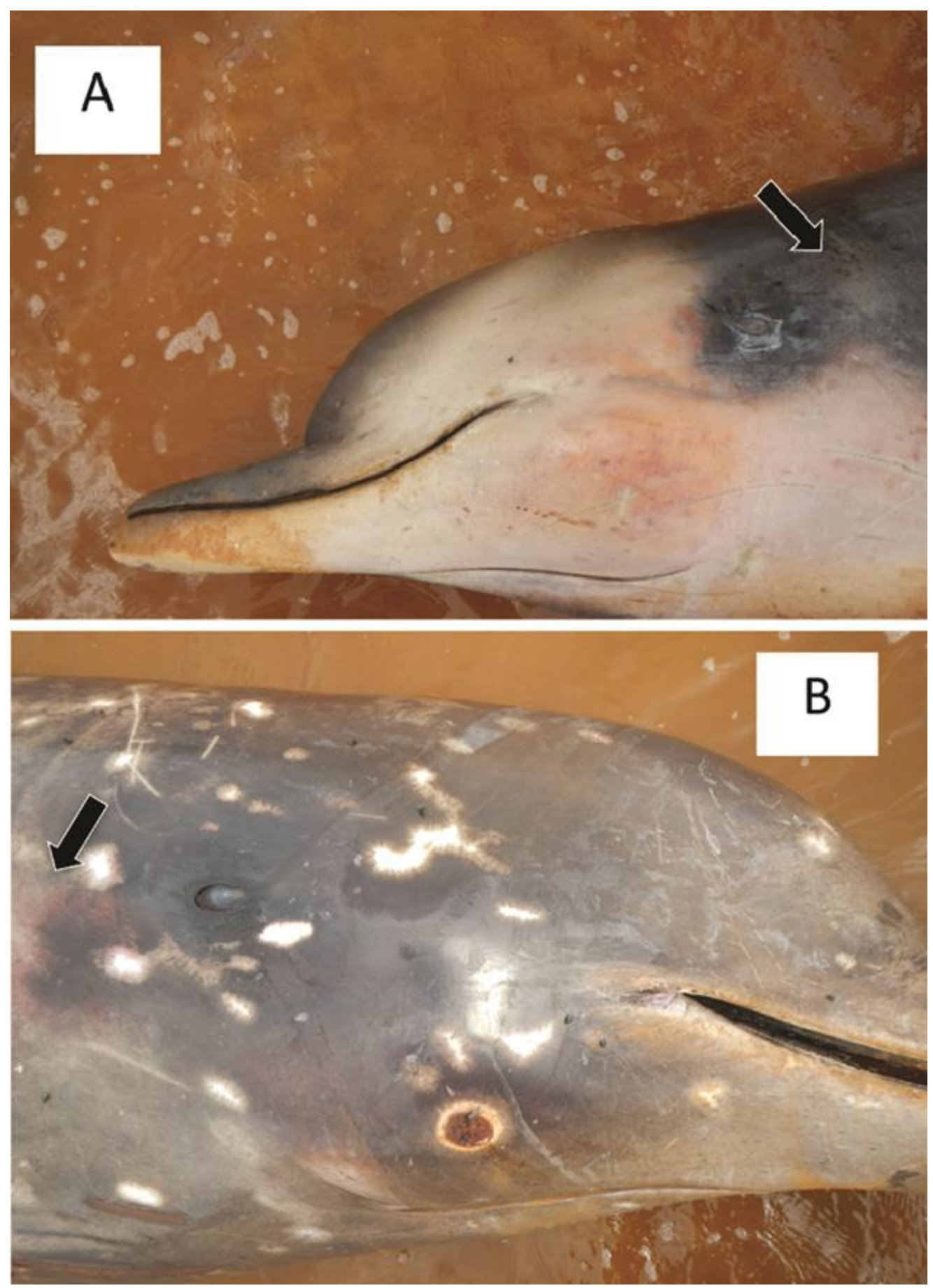

Figure 3. Head coloration for subadult female (top, \#A) and adult female (bottom, \#C). The latter also has a large number of white cookie-cutter shark bite scars. The arrow marks position of the pale 'ear patch' in the subadult female. For the adult female, this feature is just out of the picture. The coloration of the adult male (\#2) was not substantially different from the adult females. Photocredit: M. Poupon. 


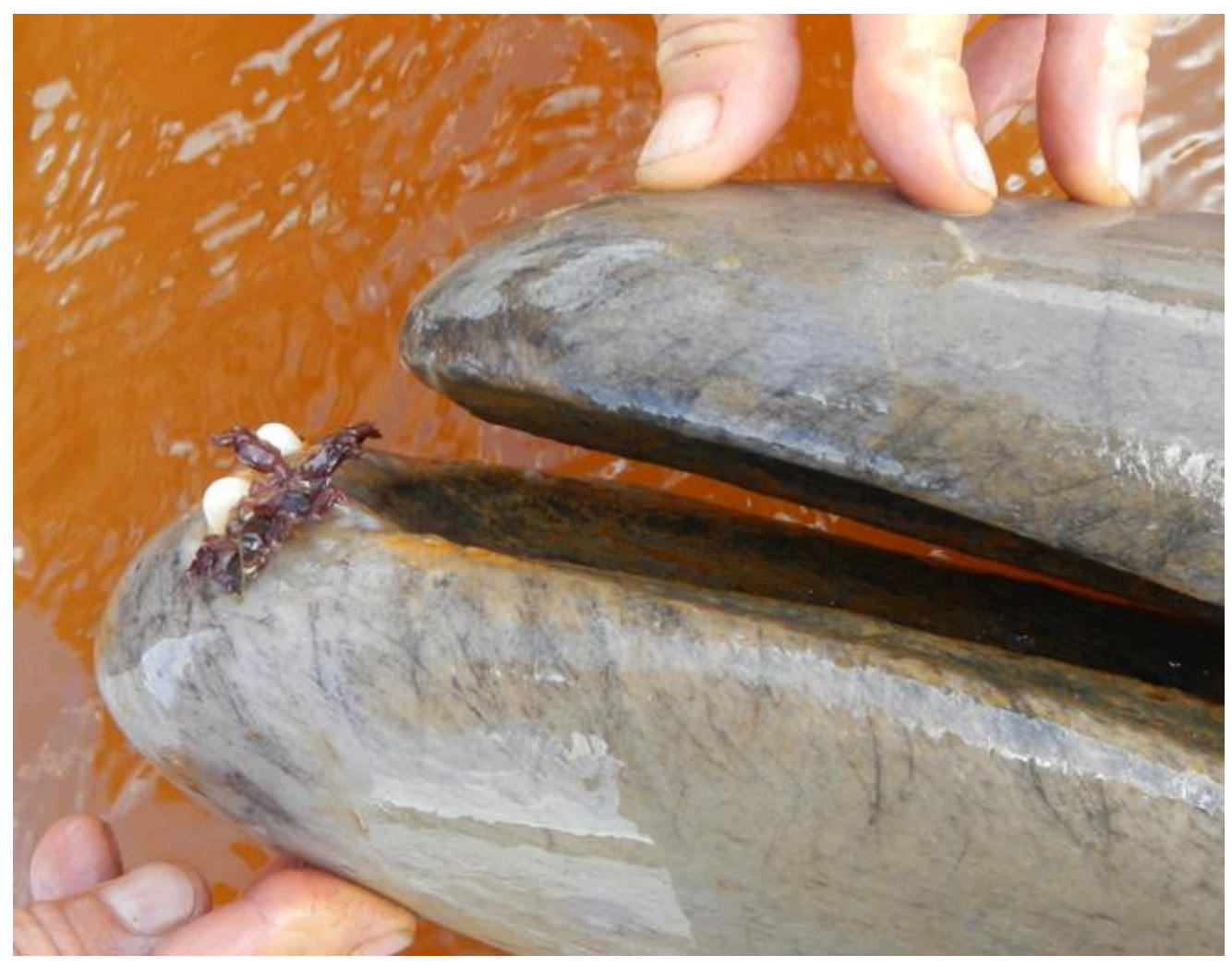

Figure 4. The single pair of apical teeth in the lower jaw of the adult male (\#2). Soft barnacles can be seen growing at the base of the teeth. The tips of the teeth are rounded and worn. Photocredit: R. Dodemont. 


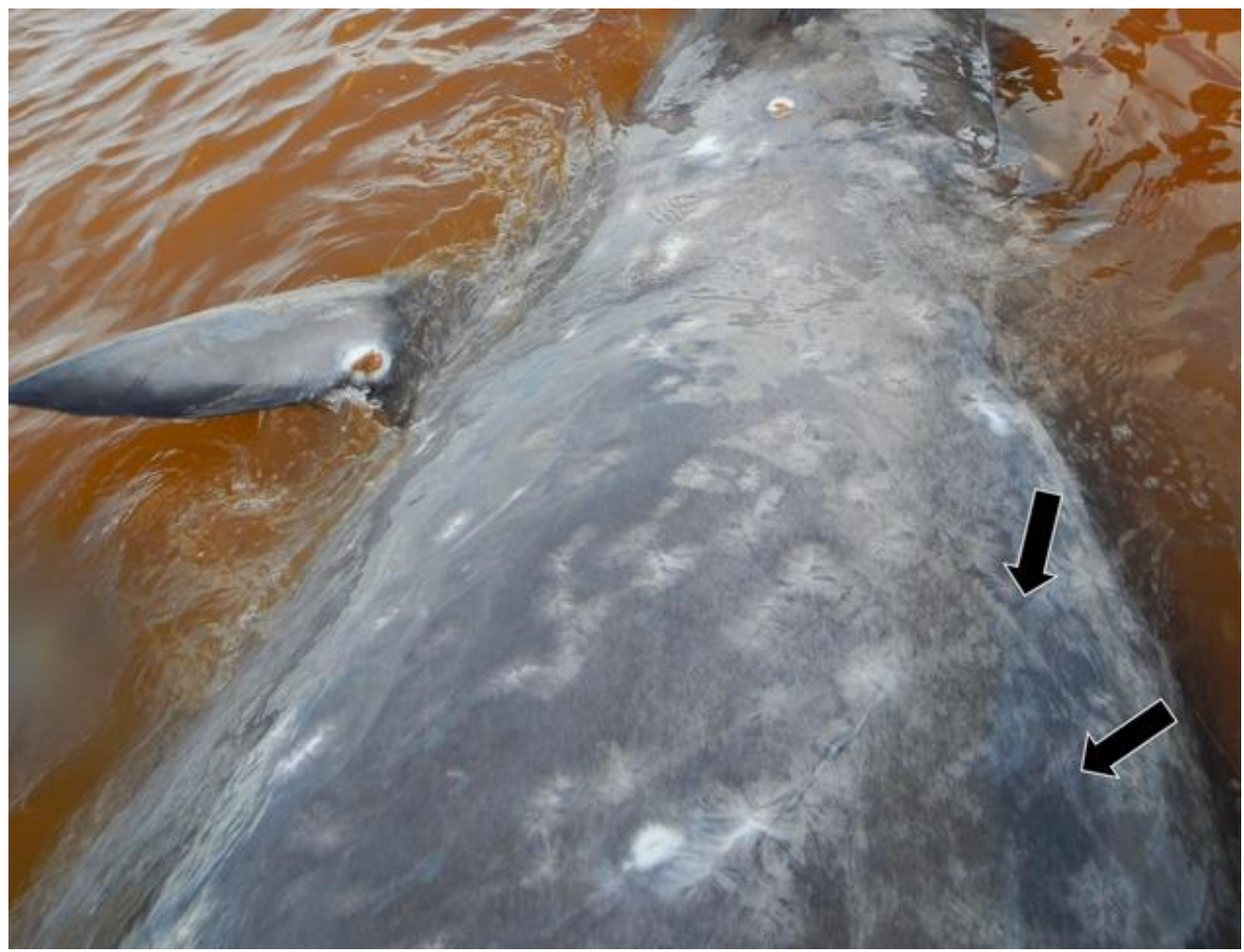

Figure 5. Flanks and back of the adult male (\#2) showing linear tooth rake scars among the circular cookie-cutter shark scars. Photo credit: R. Dodemont. 

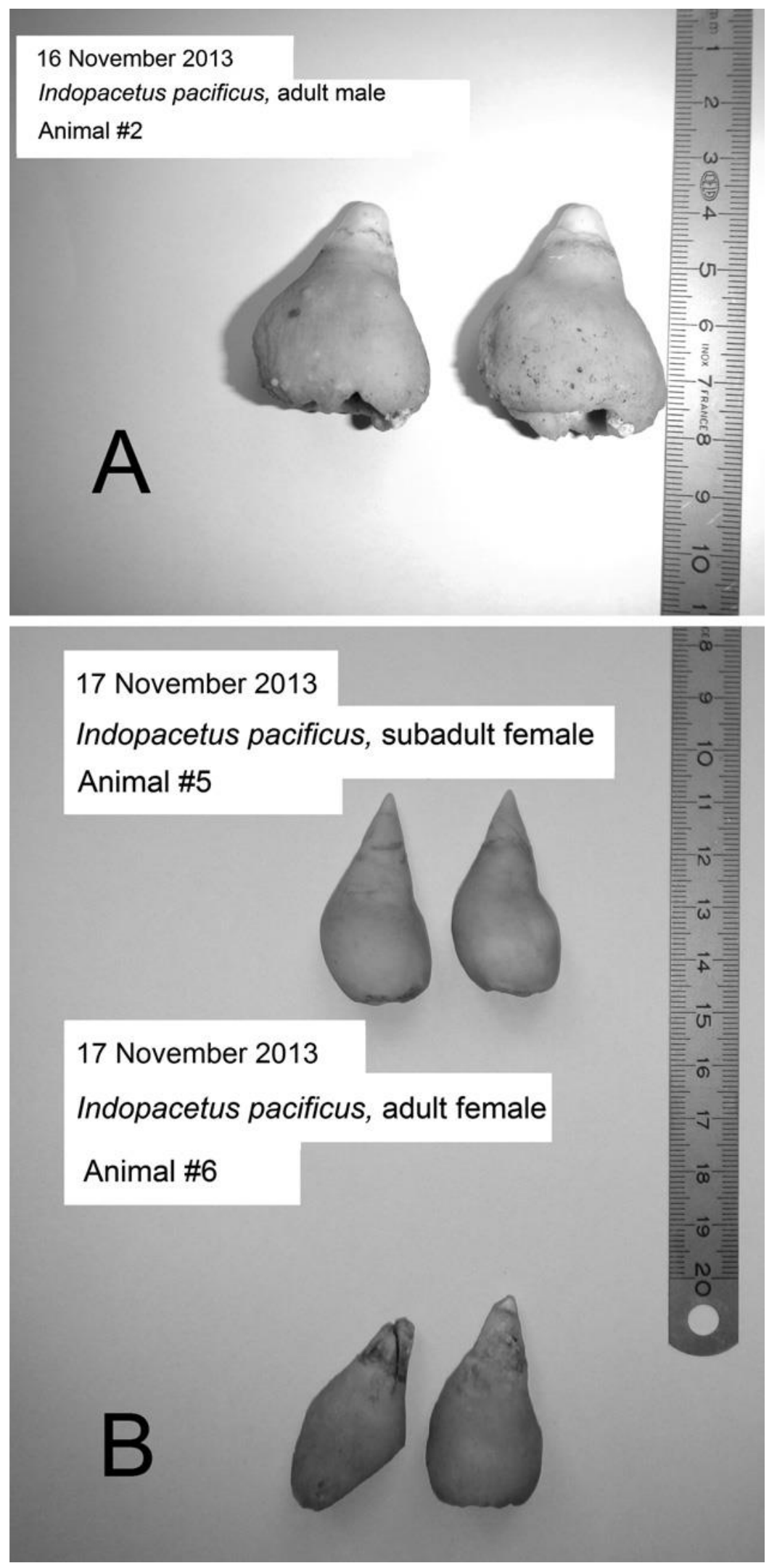

Figure 6. The pair of conical, apical teeth possessed by each whale. A, adult male (\#2). B, subadult female (\#5) and adult female (\#6). For the subadult and adult females, these teeth were unerupted and covered by gum tissue. Only the teeth of the adult male were visible in the lower jaw in life. The cut on left tooth of \#6 was sustained during specimen preparation. Photo credit: C. Garrigue. 


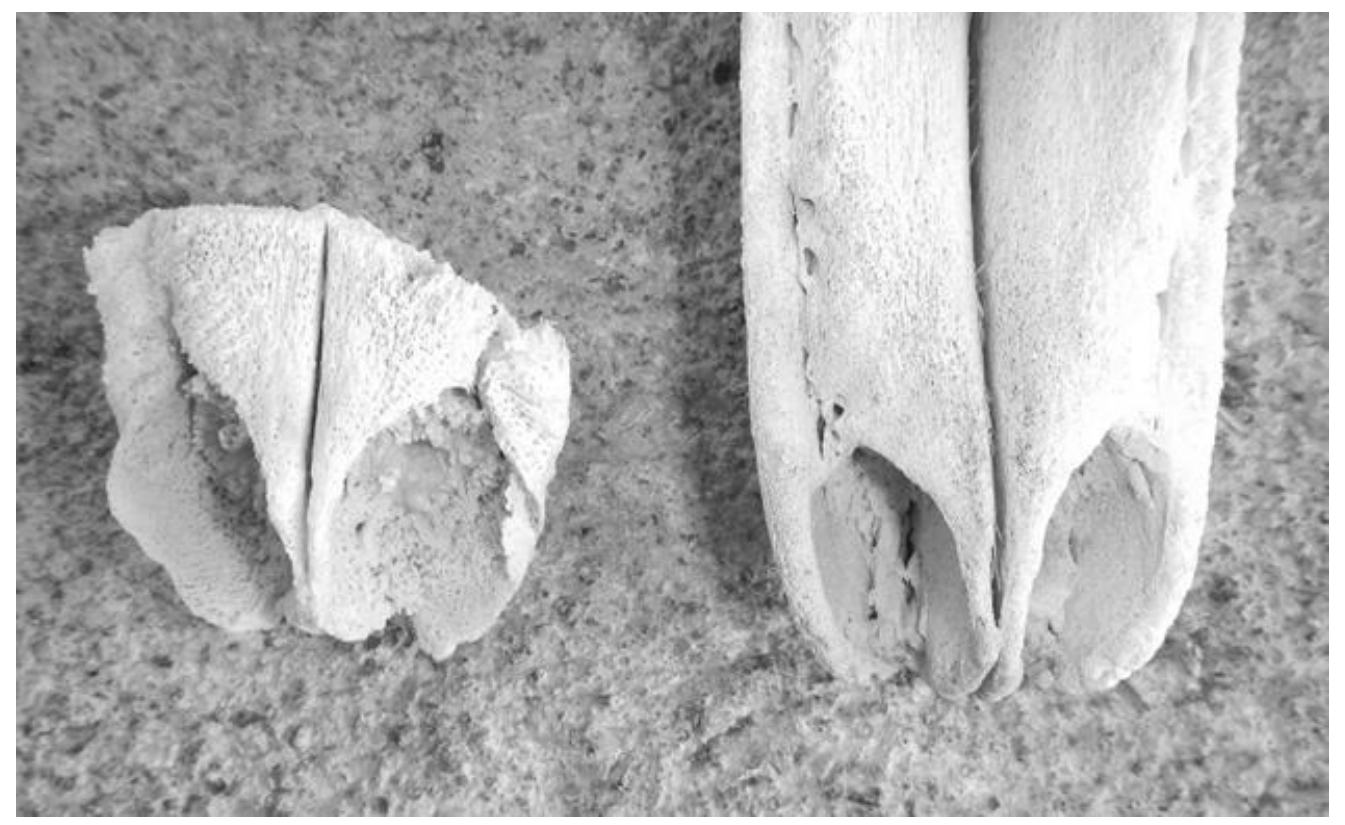

Figure 7. Tooth sockets (alveoli) in the lower jaw of adult male (left, \#2) and subadult female (right, \#5). Photo credit: C. Garrigue. 

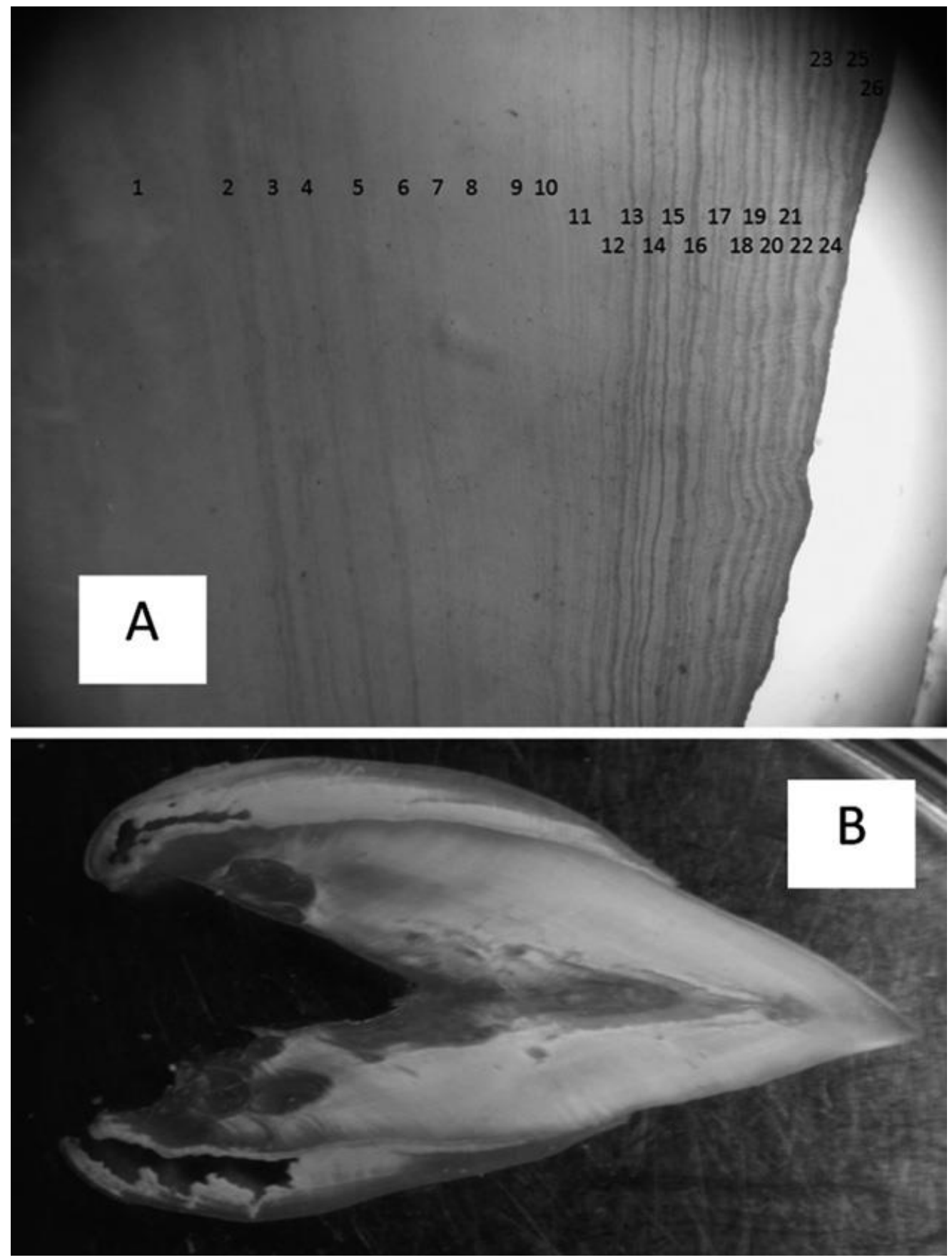

Figure 8. A) Stained, sectioned tooth from whale \#2 (adult male) used for age estimation, indicating growth layer groups (GLGs) in the cementum. (B) Extensive resorption of tissue in the root dentine of the tooth of whale \#4 (subadult female). Photo credits: C. Lockyer. 


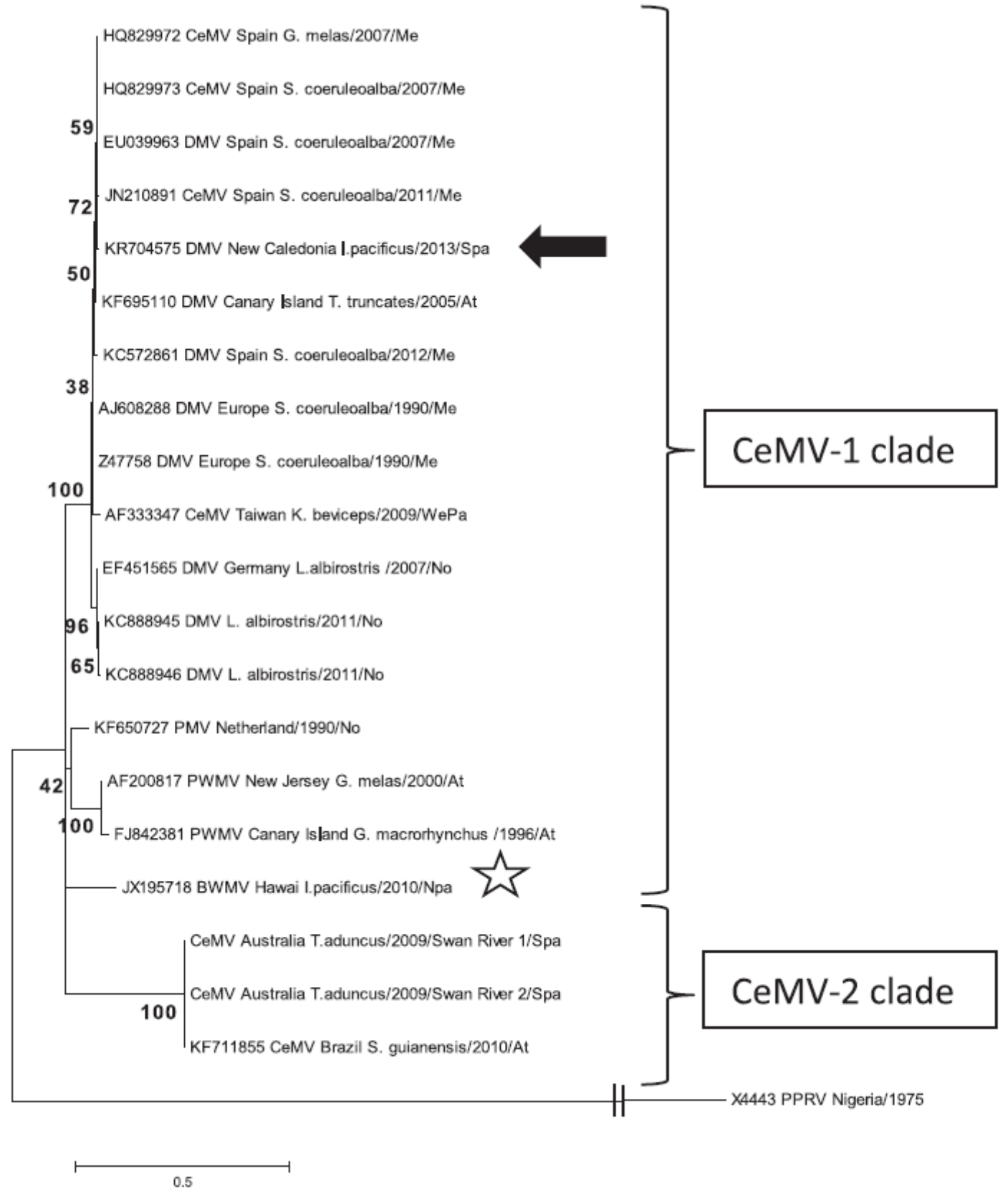

Figure 9. Phylogenetic relationships among cetacean morbillivirus strains based on analysis of 280 nucleotides of the $\mathrm{P}$ gene as obtained from GenBank using the neighbor-joining distance method. The Nigeria 75-1 vaccine strain of peste des petits ruminants (X4443), a morbillivirus found in terrestrial artiodactyls was used as an outgroup. The scale bar indicates the expected nucleotide changes per site. A black arrow highlights the New Caledonia Longman's beaked whale strain found in this study which forms part of the CeMV-1 clade. A white star indicates the strain found in a Longman's beaked whale in Hawaii (West et al. 2013) which forms part of the CeMV-2 clade. Sequence names include: GenBank Accession Numbers (where available); the name of the strain (BWMV, beaked whale morbillivirus; CeMV, cetacean morbillivirus; DMV, dolphin morbillivirus; PWMV, pilot whale morbillivirus; PMV, porpoise morbillivirus; PPRV, peste-des-petits-ruminants virus); the species; year and region (Me, Mediterranean Sea; Npa, North Pacific Ocean; Spa, South Pacific Ocean; WePa,West Pacific Ocean; No, North Sea; At, Atlantic Ocean). 